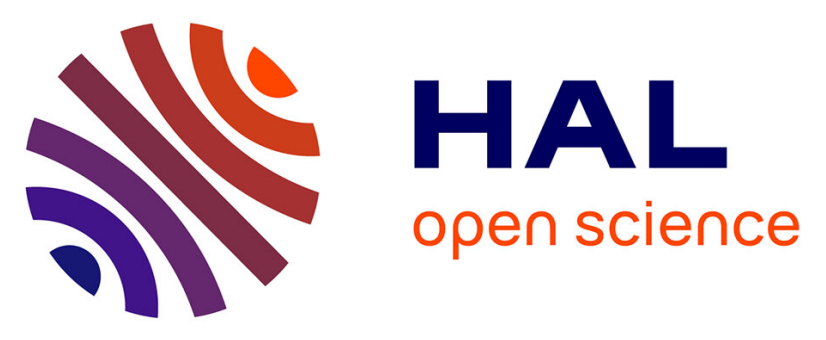

\title{
Two-dimensional electrophoresis database of Listeria monocytogenes EGDe proteome and proteomic analysis of mid-log and stationary growth phase cells
}

Patrice Folio, Patrick Chavant, Ingrid Chafsey, Abdel Belkorchia, Christophe C. Chambon, Michel Hébraud

\section{- To cite this version:}

Patrice Folio, Patrick Chavant, Ingrid Chafsey, Abdel Belkorchia, Christophe C. Chambon, et al.. Two-dimensional electrophoresis database of Listeria monocytogenes EGDe proteome and proteomic analysis of mid-log and stationary growth phase cells. Proteomics, 2004, 4 (10), pp.3187-3201. 10.1002/pmic.200300841 . hal-02681938

\section{HAL Id: hal-02681938 \\ https://hal.inrae.fr/hal-02681938}

Submitted on 1 Jun 2020

HAL is a multi-disciplinary open access archive for the deposit and dissemination of scientific research documents, whether they are published or not. The documents may come from teaching and research institutions in France or abroad, or from public or private research centers.
L'archive ouverte pluridisciplinaire HAL, est destinée au dépôt et à la diffusion de documents scientifiques de niveau recherche, publiés ou non, émanant des établissements d'enseignement et de recherche français ou étrangers, des laboratoires publics ou privés. 


\title{
Two-dimensional electrophoresis database of Listeria monocytogenes EGDe proteome and proteomic analysis of mid-log and stationary growth phase cells
}

\author{
Patrice Folio', Patrick Chavant ${ }^{1}$, Ingrid Chafsey ${ }^{1}$, Abdel Belkorchia ${ }^{1}$, \\ Christophe Chambon ${ }^{2}$ and Michel Hébraud ${ }^{1,2}$ \\ ${ }^{1}$ Station de Recherches sur la Viande-Microbiologie \\ ${ }^{2}$ Plate Forme Protéomique, \\ Saint-Genès Champanelle, France
}

Listeria monocytogenes is the causative agent of listeriosis, one of the mo\#st significant foodborne diseases in industrialized countries. The complete genome of the $L$. monocytogenes EGDe strain, belonging to the serogroup $1 / 2 \mathrm{a}$, has been sequenced and is comprised of 2853 open reading frames. The objective of the current study was to construct a two-dimensional (2-D) database of the proteome of this strain. The soluble protein fractions of the microorganism were recovered either in the mid-log or in the stationary phase of growth at $37^{\circ} \mathrm{C}$. These fractions were analyzed by 2-D electrophoresis (2-DE), using immobilized pH gradient strips of various $\mathrm{pH}$ values $(3-10,3-6$, and $5-8)$ for the first-dimensional separations and $12.5 \%$ acrylamide gels for sodium dodecyl sulfate-polyacrylamide gel electrophoresis (SDSPAGE). 201 protein spots corresponding to 126 different proteins were identified by matrix assisted laser desorption/ionization-time of flight-mass spectrometry (MALDI-TOF-MS). The 2-DE maps presented here provide a first basis for further investigations of protein expression in $L$. monocytogenes. In this way, the comparison of proteome between cells in the exponential or stationary phase of growth at $37^{\circ} \mathrm{C}$ allowed us to characterize 161 variations in protein spot intensity, of which 38 were identified. Among the differentially expressed proteins were ribosomal proteins (RpsF, RplJ, and RpmE), proteins involved in cellular metabolism (GIpD, PdhD, Pgm, Lmo1372, Lmo2696, and Lmo2743) or in stress adaptation (GroES and ferritin), a fructose-specific phosphotransferase enzyme IIB (Lmo0399) and different post-translational modified forms of listeriolysin (LLO).

Keywords: Listeria monocytogenes / Matrix assisted laser desorption/ionization-time of flight-mass spectrometry / Mid-log and stationary phase of growth / Proteome / Two-dimensional gel electrophoresis database

\begin{tabular}{|lr|}
\hline Received & $1 / 12 / 03$ \\
Revised & $5 / 3 / 04$ \\
Accepted & $8 / 3 / 04$ \\
\hline
\end{tabular}

\section{Introduction}

Listeria monocytogenes is a Gram-positive facultative anaerobic rod that can be isolated from a large diversity of biotopes including soil, water and hydraulic networks, vegetables, human and animal faeces, foodstuffs and food industrial environments. It is one of the major foodborne pathogenic bacteria and the causative agent of listeriosis, a very serious localized or generalized infection

Correspondence: Dr. Michel Hébraud, Station de Recherches sur la Viande-Microbiologie/Plate Forme Protéomique, INRA site de Theix, F-63122 Saint-Genès Champanelle, France

E-mail: hebraud@clermont.inra.fr

Fax: $+33(0)-473-624268$ which can be lethal, particularly for high-risk groups such as elderly, pregnant women, neonates, and immunocompromised individuals [1]. A series of epidemic outbreaks in the last two decades has initiated research efforts to determine the role of foods and food processing in the epidemiology. The raw materials are extensively contaminated and, consequently, so are the food production plants and foodstuffs. Obviously, these bacteria are able to survive hostile environments and stress conditions such as those encountered in food-processing technologies [2-5]. They tolerate high salt concentrations (up to $15 \%$ ), a wide range of $\mathrm{pHs}$ (from 4.5 to 9.6) and temperatures (from 0 to $45^{\circ} \mathrm{C}$ ), and low water availability ( $A w$ down to $0.91-0.93)$. Therefore, it is very important to under- 
stand the mechanisms of survival and adaptation of $L$. monocytogenes, as well as the molecular mechanisms underlying its virulence.

For several years, we have been involved in research concerning the mechanisms of adaptation of foodborne bacteria to the environmental stresses encountered in the food industry [6-8] and the properties of bacteria growing in biofilms [9-11]. These studies were carried out by different approaches and particularly by the proteomic approach that consisted of the comparison of proteome variations and the identification of selected proteins by microsequencing or Western blots. However, the combination of recent advances in protein identification, by mass spectrometry (MS), and the knowledge of the whole L. monocytogenes genome sequence [12], has allowed identification on a large number of protein spots on 2-DE gels. To date, several 2-DE databases have been established on proteome of human or animal fluids and organs [13-15] and on proteomes of microorganisms, such as Bacillus subtilis [16], Escherichia coli [17], Haemophilus influenzae [18], Streptococcus thermophilus [19], Mycobacterium tuberculosis [20], Corynebacterium glutamicum [21], and Saccharomyces cerevisiae [22]. Most of these 2-DE maps are available on the Internet and give an important complement to the genetic information.

The aim of the present study was to establish 2-DE reference maps of $L$. monocytogenes soluble proteins, which could aid basic physiological investigations on mechanisms involved in environmental survival, adaptation, and in virulence. In order to obtain a larger recovery and a better resolution of the bacterial proteome, cells were recovered either in mid-log or stationary phases of growth and three different $\mathrm{pH}$ gradients were carried out for the firstdimensional separation. The identification of protein spots was by MALDI-TOF-MS. In this communication, we describe the present status of this proteome project and we point out some important variations in protein expression between mid-log and stationary growth phase.

\section{Materials and methods}

\subsection{Materials}

Immobilized pH gradient (IPG) strips, acrylamide solution and ampholytes were obtained from Bio-Rad (Hercules, CA, USA). Ammonium persulfate, TEMED, 3-(3-cholamido-propyl)dimethylammonio-1-propane sulfonate (CHAPS), EDTA, glycine, iodoacetamide, glycerol, sodium thiosulfate, Coomassie Brilliant Blue $\mathrm{G}$, deoxyribonuclease I (Dnase I), ribonuclease A (Rnase A) and sodium carbonate were purchased from Sigma-Aldrich
(St. Louis, MO, USA). Tris, tributylphosphine (TBP), acetonitrile, and trifluoroacetic acid (TFA) were from Fluka (Buchs, Switzerland). Urea was purchased from Calbiochem (EMD Biosciences, San Diego, CA, USA) and thiourea and silver nitrate from Merck (NJ, USA). Sodium dodecyl sulfate (SDS) was purchased from USB (Cleveland, $\mathrm{OH}, \mathrm{USA})$.

\subsection{Bacterial growth conditions}

The L. monocytogenes EGDe strain, serogroup 1/2a, was kindly provided by P. Cossard (Institut Pasteur, Paris). The strain was precultured and cultured in an orbital shaking water bath $(150 \mathrm{rpm})$ at $37^{\circ} \mathrm{C}$ with brain heart infusion (BHI) medium (Difco, Detroit, MI, USA). Growth was monitored by measuring the absorbance at $600 \mathrm{~nm}\left(\mathrm{OD}_{600}\right)$. Precultured cells in stationary phase were used to inoculate cultures in order to obtain a final $\mathrm{OD}_{600}$ of 0.1 (approximately $10^{7} \mathrm{CFU} / \mathrm{mL}$ ). The strain was grown until the midlog or the stationary phase, i.e., $3 \mathrm{~h}\left(\mathrm{OD}_{600} \approx 0.7\right)$ and $17 \mathrm{~h}$ $\left(O D_{600} \approx 1.3\right)$, respectively.

\subsection{Preparation of $L$. monocytogenes soluble protein samples}

After sampling by centrifugation $(7500 \times g, 15 \mathrm{~min})$, cell pellets were washed twice with TE buffer $(20 \mathrm{~mm}$ Tris$\mathrm{HCl}, \mathrm{pH}$ 7.5; 5 mM EDTA; $5 \mathrm{~mm} \mathrm{MgCl}_{2}$ ), then resuspended in TE buffer, $\mathrm{pH} 9.0$, and stored at $-20^{\circ} \mathrm{C}$ until their treatment. To optimize the yield of protein extraction, different protocols were evaluated, in particular enzymatic lysis using different concentrations of lysosyme, combined or not with sonication or a mechanical treatment using glass beads. The extraction buffer was also tested by using TBP instead of DTT as reducing agent. The best results, in terms of quantity of extracted proteins and number of spots resolved by 2-DE, were obtained by the following method. The bacteria were sonicated with a Vibracell sonifier (Bioblock Scientific, Illkirch, France) three times for $2 \mathrm{~min}$ at power level 5 and $50 \%$ of the active cycle. The samples were then treated with Dnase I and Rnase A for $30 \mathrm{~min}$ at room temperature. A solution was added at a final concentration of $4 \mathrm{M}$ urea, $2 \mathrm{M}$ thiourea, $2 \% \mathrm{w} / \mathrm{v}$ CHAPS, and $2 \mathrm{~mm}$ TBP, and the incubation was allowed to continue for $30 \mathrm{~min}$ on ice with intermittent agitation. The soluble protein fractions were separated from cell debris by centrifugation at $13000 \times g$ for $20 \mathrm{~min}$. The protein concentrations were determined for each fraction by the method of Bradford [23] using the Bio-Rad protein assay kit. Bovine serum albumin was used as the standard. The protein samples were precipitated with three volumes of cold acetone at $-20^{\circ} \mathrm{C}$ during at least $2 \mathrm{~h}$ and then pelleted by centrifugation $(13000 \times \mathrm{g}, 40 \mathrm{~min})$. 
Pellets were resuspended in isoelectric focusing (IEF) buffer (7 $\mathrm{m}$ urea, $2 \mathrm{~m}$ thiourea, $4 \% \mathrm{w} / \mathrm{v}$ CHAPS, and a trace of bromophenol blue) at a concentration of $5 \mathrm{mg} / \mathrm{mL}$ proteins and stored at $-20^{\circ} \mathrm{C}$.

\subsection{Two-dimensional electrophoresis}

2-DE was performed essentially according to the principles of O'Farrell [24] with few adaptations. For IEF, precast IPG strips with linear gradients of $\mathrm{pH} 3-10, \mathrm{pH} 3-6$ or $\mathrm{pH} \mathrm{5-8}$ were passively rehydrated overnight in a reswelling tray with $400 \mu \mathrm{L}$ IEF buffer containing $1.5 \%$ $\mathrm{v} / \mathrm{v}$ ampholytes adapted to the $\mathrm{pH}$ gradient, $2 \mathrm{~mm}$ TBP, and 60,50 or $50 \mu \mathrm{g}$ of proteins, respectively. Proteins were separated using a Multiphor II electrophoresis unit (Amersham Biosciences, Uppsala, Sweden). To improve the protein separation, low voltages (50 V, then 200 or $500 \mathrm{~V}$ according to the IPG strips) were applied at the beginning. IEF was then continued with maximum setting up to $3500 \mathrm{~V}$ at a focusing temperature of $19^{\circ} \mathrm{C}$. The time necessary to reach a steady state was dependent on the $\mathrm{pH}$ gradient : $36500 \mathrm{Vh}$ for $\mathrm{pH}$ 3-10 IPG gels, $59000 \mathrm{Vh}$ for pH 3-6 IPG gels, and $79000 \mathrm{Vh}$ for pH 5-8 IPG gels. Focused IPG strips were stored at $-20^{\circ} \mathrm{C}$ in plastic bags. Prior to running the second dimension, strips were equilibrated twice for $15 \mathrm{~min}$ in an equilibration solution $(50 \mathrm{~mm}$ Tris- $\mathrm{HCl}, \mathrm{pH} 8.8,6 \mathrm{~m}$ urea, $2 \% \mathrm{w} / \mathrm{v}$ SDS, $30 \% \mathrm{v} / \mathrm{v}$ glycerol) containing $5 \mathrm{~mm}$ TBP for the first step and $2.5 \% \mathrm{w} / \mathrm{v}$ iodoacetamide and a trace of bromophenol blue for the second step. The second dimension (SDS-PAGE) was carried out with $12.5 \% \mathrm{~T}, 3.3 \% \mathrm{C}$ polyacrylamide gels in a Multicell Protean II XL system (Bio-Rad). Six gels $(190 \times 185 \mathrm{~mm})$ of $1 \mathrm{~mm}$ width, without stacking gel, were run simultaneously until the marker dye had reached the bottom of the gel.

\subsection{Staining of 2-DE gels and image analysis}

Routinely, proteins in gels used to establish reference maps were silver stained according to a modified procedure [25] of Blum et al. [26]. For the identification of protein spots, semipreparative conditions were used. The 2-DE gels were carried out with $800 \mu \mathrm{g}$ of proteins and spots were detected using colloidal Coomassie blue stain according to the protocol of Neuhoff et al. [27]. Stained 2-DE gels were scanned by a GS-700 imaging densitometer (Bio-Rad) and image analysis was performed using Melanie III (release 3.03) 2-DE analysis software (Genebio, Geneva, Switzerland). The reference 2-DE maps were established with at least four gels per growth condition and $\mathrm{pH}$ gradient from two independent bacterial cultures and protein extractions. For the image analysis and comparison, only spots present in at least $n-1$ gels, $n$ being the number of gels run for each condition, were taken into account. The molecular masses were determined by running standard protein markers (Bio-Rad), covering the range of $6.5-200 \mathrm{kDa}$, during the second dimension. The $\mathrm{pl}$ values were determined according to information provided by the supplier of IPG strips.

\subsection{Peptide mass fingerprinting}

\subsubsection{In-gel digestion}

The protein spots on semipreparative 2-DE gels were removed using pipette cones, cut to the diameter of each spot. The gel pieces were put into a 96-well plate then destained and digested using the Montage In-Gel Digest $_{96}$ Kit (Millipore, Bedford, MA, USA) according to the supplier protocol except for the trypsin which was purchased from Promega (Madison, WI, USA). Briefly, removed spots were washed several times with the destaining solution, then dehydrated with $100 \%$ acetonitrile. The dried gels were reswollen in $50 \mu \mathrm{L}$ of trypsin solution containing $300 \mathrm{ng}$ trypsin and incubated overnight at $37^{\circ} \mathrm{C}$. Resulting peptides were extracted with $50 \mu \mathrm{L}$ of extraction solution, then the mixtures were concentrated in a Speedvac evaporator to a maximum volume of $10 \mu \mathrm{L}$. The samples were desalted using $\mu \mathrm{C} 18-$ ZipTip $^{\text {TM }}$ (Millipore, Bedford, MA, USA) as recommended by the manufacturer. Finally, the peptide mixture was eluted from the ZipTip with $60 \%$ acetonitrile, 0.1\% TFA.

\subsubsection{MALDI-TOF-MS}

For MALDI-TOF-MS, $1 \mu \mathrm{L}$ of each sample and $1 \mu \mathrm{L}$ saturated $\alpha$-cyano-4-hydroxycinnamic acid matrix $(10 \mathrm{mg} /$ $\mathrm{mL}$ ) prepared in 50\% acetonitrile, $0.1 \%$ TFA were mixed onto the target and the mixture was allowed to dry. Positive ion MALDI mass spectra were recorded in the reflectron mode of a MALDI-TOF-MS (Voyager DE-Pro; PerSeptive BioSystems, Framingham, MA, USA) using Voyager software for data collection and analysis. The MS was calibrated with a standard peptide solution (Proteomix; LaserBio Labs, Sophia-Antipolis, France). Internal calibration of samples was achieved by using trypsin autolysis peptides. Monoisotopic peptide masses were assigned and used for NCBI database searches with the "Mascot" software (http://www.matrixscience.com). The following parameters were considered for the searches: a maximum fragment ion mass tolerance of $\pm 25 \mathrm{ppm}$, a maximum of one missed enzymatic cleavage, modification of cysteines by carbamidomethylation and possible oxidation of methionine. 


\section{Results and discussion}

\subsection{Hypothetical 2-DE map of L. monocytogenes EGDe proteins}

A hypothetical 2-DE map was prepared using theoretical masses and $\mathrm{pl}$ of amino acid sequences of the bacteria provided from the database of Pasteur Institut (http://genolist.pasteur.fr/ListiList/). This virtual 2-DE map is shown in Fig. 1. As in a similar display for $B$. subtilis [16] and $E$. coli [28], this virtual map showed two clusters, with a clear border around $\mathrm{pH} 8$. The majority of $L$. monocytogenes proteins were localized in a region between $\mathrm{pH} 4$ and 10 and between $M_{\mathrm{r}} 7.5$ and $100 \mathrm{kDa}$.

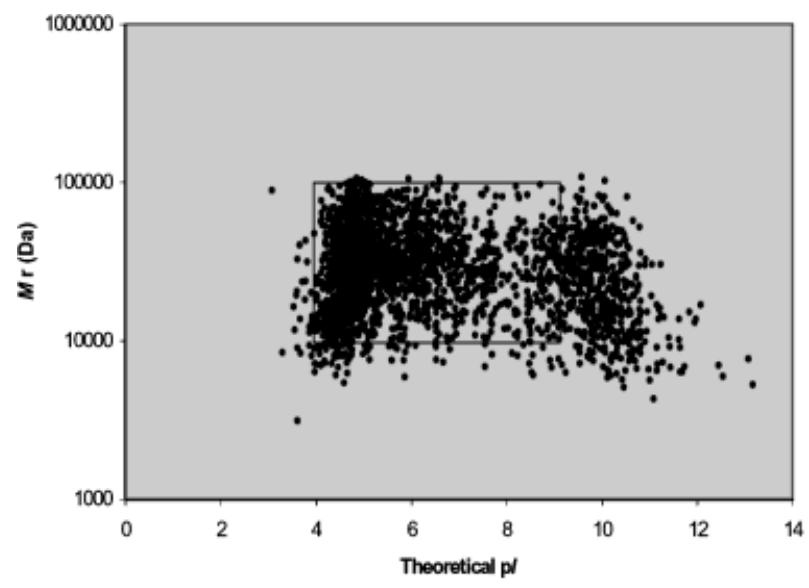

Figure 1. Hypothetical 2-DE map of $L$. monocytogenes EGDe proteins. Theoretical mass and p/ of the 2853 ORF of the strain were plotted. The boxed area indicates the separation range under the 2-DE conditions used in this study.

\subsection{Analysis of the soluble protein fraction of L. monocytogenes EGDe}

The soluble protein fraction of $L$. monocytogenes EGDe grown until the stationary phase in $\mathrm{BHI}$ broth at $37^{\circ} \mathrm{C}$ was used to establish the reference 2-DE maps. A large view of the $L$. monocytogenes protein content was obtained by using pH 3-10 IPG strips for IEF separation. A total of about 900 spots were detected in the silver-stained gels, the majority of them were localized in the $\mathrm{pH}$ range 4-8 (Fig. 2A). Considering this result and the theoretical distribution of all the predicted proteins of $L$. monocytogenes EGDe, we used two other overlapping and narrowest $\mathrm{pH}$ gradients, $\mathrm{pH}$ 3-6 IPG strips (Fig. 2B) and pH 5-8 IPG strips (Fig. 2C), to gain protein resolution. The three combined $\mathrm{pH}$ gradients theoretically allowed the separation and resolution of about 2220 protein precursors (over 2853 annotated
ORF) covering $78 \%$ of the strain proteome (Fig. 1). Experimentally, the combination of the three $\mathrm{pH}$ gradients resolved about 1300 different silver-stained spots for the cytoplasmic fraction.

The most prominent and well-separated spots were analyzed by MALDI-TOF-MS for identification on the basis of peptide mass fingerprint matching. The 126 identified proteins, representing $4.4 \%$ of the $L$. monocytogenes potential gene products, were localized on the 2-DE reference maps (Fig. 2), and referenced with an identification number. The names and specific information on each of the proteins are listed in Table 1 (see Addendum). An alphanumeric code was assigned to each protein according to the $\mathrm{pl}$ (a to from acidic to basic range) and $M_{\mathrm{r}}$ ( 1 to 5 from high to low $M r$ ) which allowed to easily localize them on the 2-DE maps The flagellin (spot 7), the constitutive protein of $L$. monocytogenes flagella, was added to the reference maps although it was only resolved as a strong spot on 2-DE gels with protein samples from bacterial cultures at $20^{\circ} \mathrm{C}$ (data not shown). This observation was consistent with the morphological particularity of the bacterium, which is mobile between $20^{\circ}$ and $28^{\circ} \mathrm{C}$ using flagella.

Numerous proteins were resolved as two or more spots on the 2-D gels (e.g., spots 8, 9, 10, 31, 73, 76 in Fig. 2B). In fact, the 126 identified proteins corresponded to 201 spots on the 2-D gels due to post-translational modifications. This suggests that, in our growth conditions, a theoretical average value of 1.59 separate spots could be resolved on 2-DE for each open reading frame of L. monocytogenes EGDe strain, which is a similar value to that obtained for E. coli [17]. By extrapolating, we can estimate that our 2-DE reference maps (about 1300 spots) covered $28.8 \%$ of the L. monocytogenes EGDe potential gene products.

\subsection{Proteome comparison between cells in exponential and stationary phase of growth}

The proteomic approach was used to assess the differences in $L$. monocytogenes EGDe protein expression between two phases of growth in $\mathrm{BHI}$ at $37^{\circ} \mathrm{C}$. Protein extracts were prepared from cells in mid-log phase and in late-stationary phase, which corresponded to $3 \mathrm{~h}$ and $17 \mathrm{~h}$ (i.e., $8 \mathrm{~h}$ after entry in stationary state) of growth in $\mathrm{BHI}$ medium. A statistical analysis was performed using Student's $t$-test ( $95 \%$ confidence interval) to select only significant changes in spot intensity between the two phases of growth. Moreover, only spots in this confidence interval which exhibited an over- or underexpression ratio of at least twofold were taken into consideration. Spots 

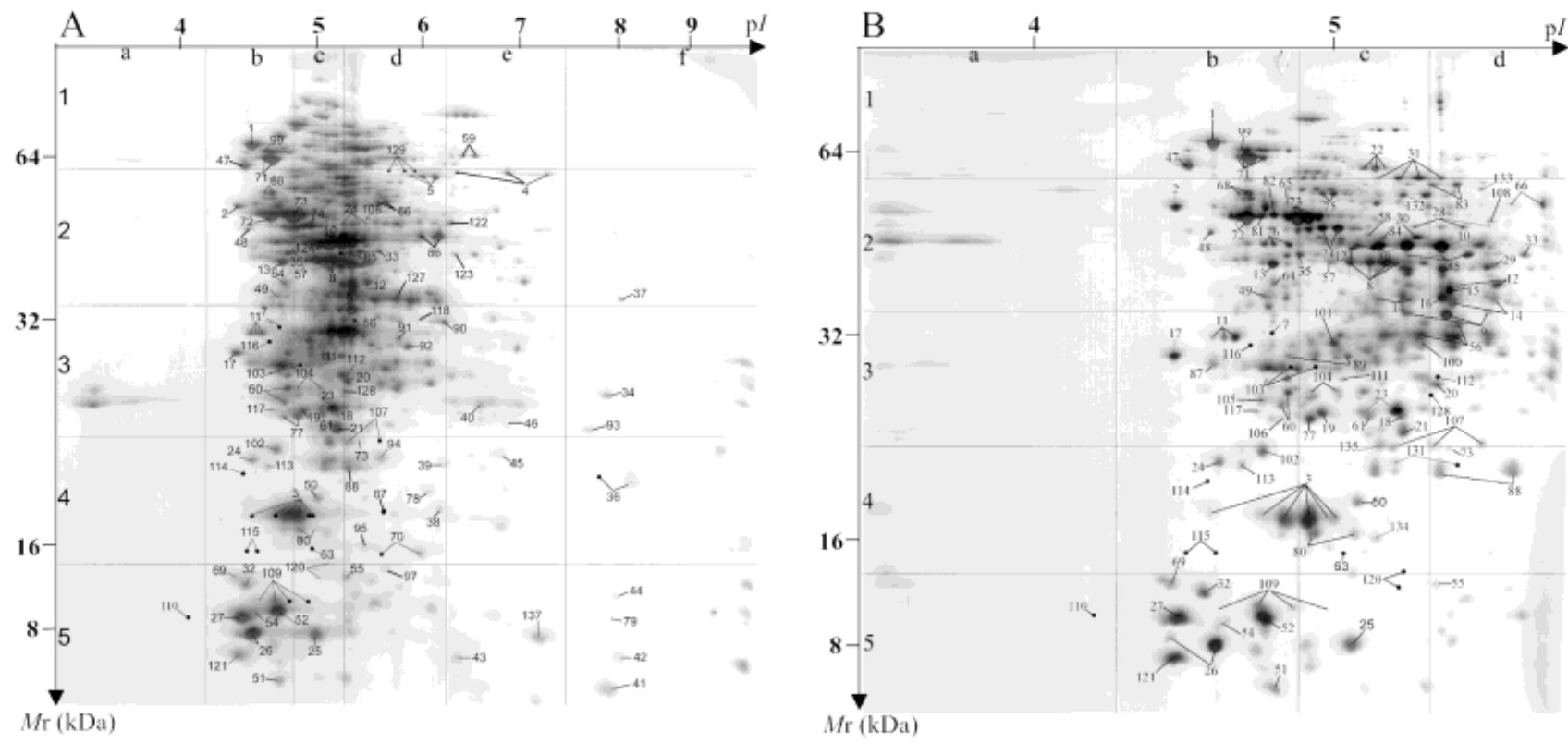

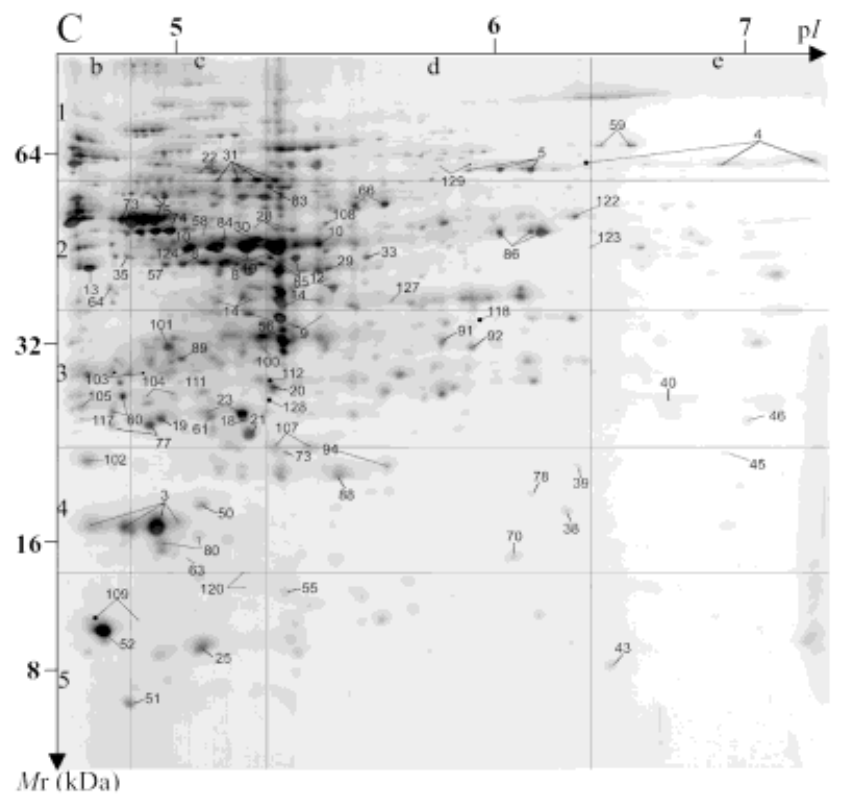

from 2-DE gels obtained with $\mathrm{pH}$ 3-6 IPG strips and resolved in the $\mathrm{pH}$ range $6-9.5$ of $\mathrm{pH} 3-10$ IPG strips, representing a total of 1149 detected spots, were selected for the comparative analysis. About 14\% (161 spots) of the proteome was affected by the growthphase. 9.2\% (106 spots) of the protein spots corresponded to overexpressed or neosynthesized proteins while $4.8 \%$ (55 spots) were underexpressed in the stationary phase by comparison to the mid-log phase. In fact, 39.6\% (42 over 106 spots) of the overexpressed spots in stationary phase corresponded to neosynthe-
Figure 2. Reference 2-DE maps of the soluble protein fraction of $L$. monocytogenes EGDe strain on (A) $\mathrm{pH} 3-$ 10 linear IPG strips, (B) pH 3-6 IPG strips, and (C) pH 5-8 IPG strips. The gels were silver-stained. The spots marked with an identification number represent proteins identified by MALDI-TOF-MS. The cross indicates a spot not visible with this protein sample. The names of the proteins are listed in Table 1 (see Addendum). The grid pattern was arbitrarily chosen to assign an alphanumeric code to each protein allowing easier localization.

sized proteins. Among the observed 161 variations in spot intensities (Fig. 3), 38 protein spots were identified by MALDI-TOF-MS and corresponded to 23 different proteins (Table 2, see Addendum).

When cells are exposed to some environmental variations or aggressions such as starvation or sudden thermal shock, they sometimes undergo growth arrest and enter in stationary phase. Due to the quorum sensing, the same event takes place when the bacterial density reaches a certain level. Stationary phase may therefore mimic a 
A

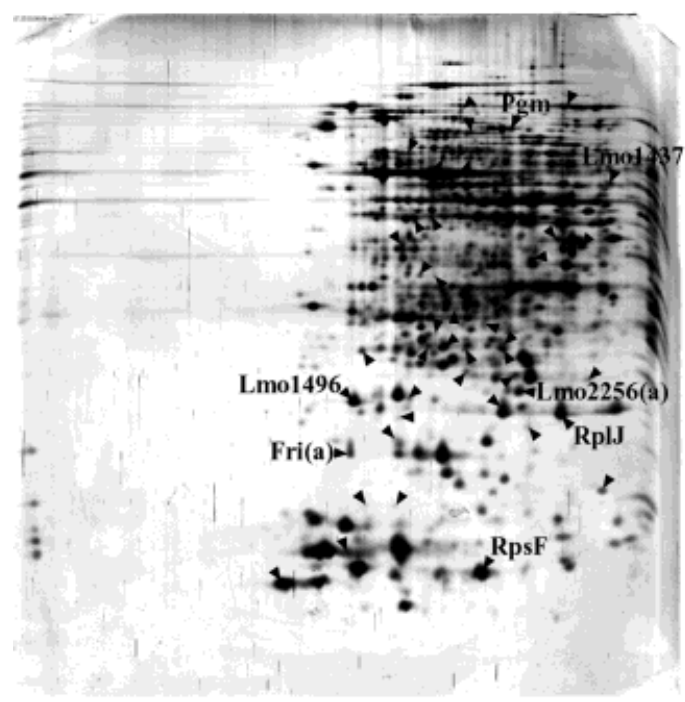

$\mathrm{C}$

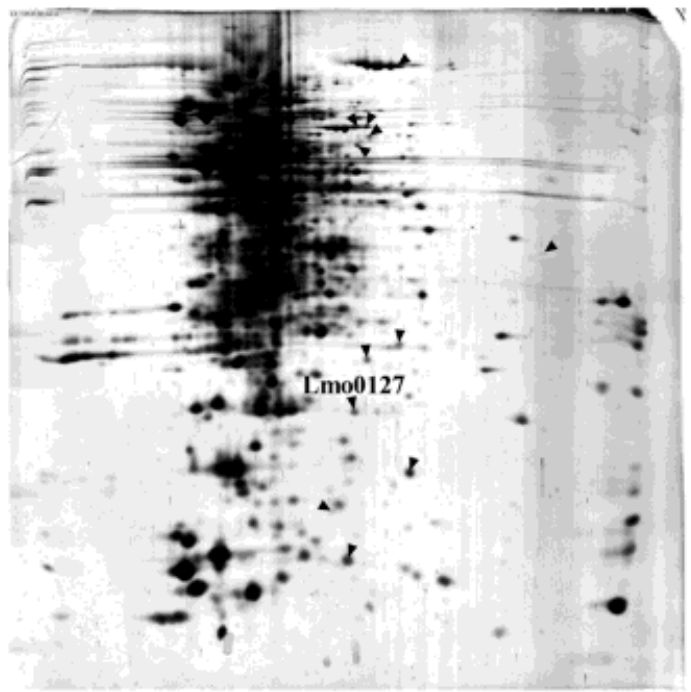

$\mathrm{B}$

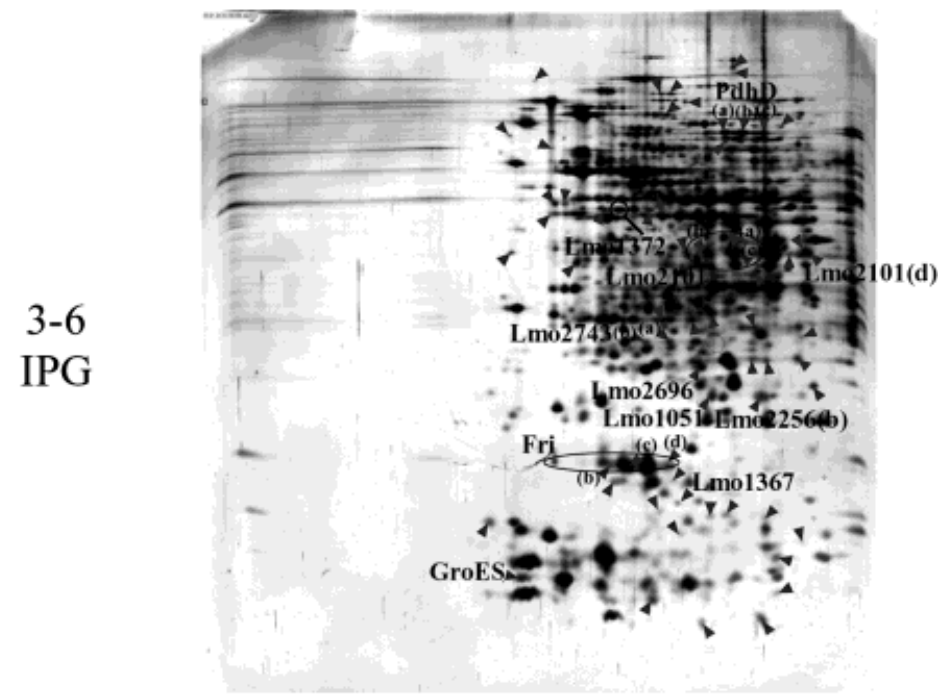

$\mathrm{D}$

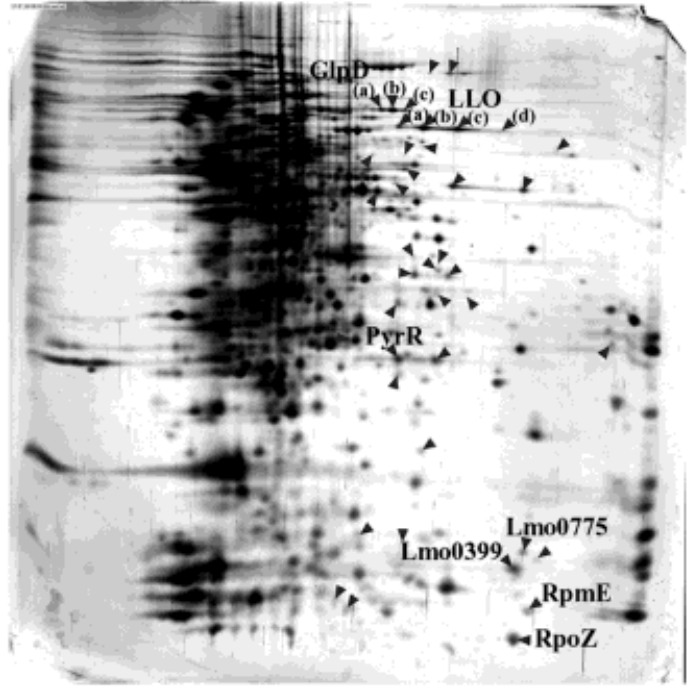

Figure 3. 2-DE maps of the soluble protein fractions of $L$. monocytogenes EGDe obtained in (A), (C) exponential or in (B), (D) stationary phase of growth. The protein extracts were separated in (A), (B) pH 3-6 IPG strips and (B), (D) pH 3-10 IPG strips. Arrows indicate the overexpressed proteins in each protein sample and numbers point out the identified spots listed in Table 2 (see Addendum). The two circled areas indicate multiple spots corresponding to two putative post-translational modified proteins.

starvation state (starvation for nutrient, oxygen, amino acid, etc.). The transition to stationary phase is accompanied by many physiological changes [31,32] due in part to modifications that occur in medium composition during the bacterial growth. Two major bacterial cell responses generally take place during this transition. The first is the stringent response, which is a pleitropic bacterial global regulatory event that is usually triggered by various nutritional and metabolic stresses in order to conserve energy
[33, 34]. It is mediated by [(p)ppGpp] and affects the expression of many genes with the general effect of an indirect reduction of protein synthesis. The second is a general stress response mediated by the alternative sigma factors RpoS and sigmaB $\left(\sigma^{\mathrm{B}}\right)$ in Gram-negative and Gram-positive bacteria, respectively. It is well-known that these factors regulate the expression of numerous genes under various environmental stress conditions and upon entry into the stationary phase [35-38]. In L. mono- 
cytogenes, Becker et al. [38] demonstrated that there is increased $L$. monocytogenes sigB transcription, which implies that there is increased $\sigma^{\mathrm{B}}$ activity, following exposure of exponentially-growing cells to different stresses as well as upon entry into the stationary phase. In B. subtilis, it has been shown that the $\sigma^{\mathrm{B}}$ general stress sigma factor regulates its own expression [39] but no evidence exists for such an auto-regulation of $L$. monocytogenes $\sigma^{\mathrm{B}}$.

Our analyses of 2-DE gels did not reveal any variation in protein spot intensity in the area corresponding to the putative localization of $\sigma^{\mathrm{B}}$. Based on previous reports $[40,41]$, we search for putative $\sigma^{\mathrm{B}}$-dependent promoter regions among the genes encoding the differentially expressed proteins upon entry into the stationary phase. Interestingly, we found $\sigma^{\mathrm{B}}$ consensus patterns for several genes including rpmE (GTTTTA- $\mathrm{N}_{16}-\mathrm{GGG}$ at -205 from the start codon), rp/J (GCTTAA-N ${ }_{13}$-GGGATTTC at -157), Imo2696 (GTTTTG-N 13 -GGGAAA at -66), Imo1372 (GTTTA-N ${ }_{13}$-GGGAAG at -138), and fri (GAATAA- $\mathrm{N}_{13}{ }^{-}$ GGGATT at -157). This suggests a possible involvement of $\sigma^{\mathrm{B}}$ in the regulation of the expression of some L. monocytogenes gene during transition to the stationary phase.

Among the differentially-expressed protein spots, we found proteins involved in cellular metabolisms, RNA and protein biosynthesis, and stress adaptation. It is widely known that transition to stationary phase induces a modification in the transcriptional and translational machineries due to the stringent response. RpsF and RplJ, the $30 \mathrm{~S}$ ribosomal protein $\mathrm{S} 6$ and the $50 \mathrm{~S}$ ribosomal protein L10 respectively, were underexpressed in the stationary phase. It has been shown that the L. monocytogenes ribosome number rapidly decreased during the stationary phase [42]. Similar downregulation during the stationary phase has been reported for the E. coli rps $F$ [43] and the Streptomyces coelicolor rplJ gene [44]. In contrast, the 50 S ribosomal protein L31, named RpmE, was overexpressed. An adaptative reprogramming of the ribosomes is necessary under certain stressing growth conditions [45] and it can be assumed that the entry into a stationary phase also necessitates similar changes. Ribosomes may also represent a valuable source of metabolites to starved cells, but maintenance of an active ribosomal pool would appear to be essential for cell survival and recovery [46]. In addition, two transcriptional repressors, Lmo1367 and PyrR, were also overexpressed in the L. monocytogenes stationary phase. These proteins were involved in bacterial response to starvation, one in $B$. subtilis where PyrR represses the expression of genes involved in the pyrimidine nucleotide biosynthesis [47], and the other in E. coli, where the arginine repressor, corresponding to the Imo1367 gene product, reduces the synthesis of the arginine-biosynthesis enzymes [48]. A third protein,
Lmo1496, similar to the transcription elongation factor GreA, was found to be underexpressed. These results suggest that transition to stationary phase leads to a global reduction of RNA and protein synthesis.

Several proteins involved in cellular metabolism were overexpressed in the stationary phase. This is the case for Lmo0399, a fructose-specific phosphotransferase enzyme IIB required for the uptake of fructose and for five proteins (GlpD, PdhD, Lmo1372, Lmo2696, and Lmo2743) implicated in different metabolic pathways. In contrast, the phosphoglycerate mutase Pgm, involved in the main glycolytic pathway, was downregulated in the stationary phase. These physiological events are certainly triggered by the modifications which occur in the medium during the bacterial growth (glucose and nutrient consumption, $\mathrm{O}_{2}$ limitation, etc.).

Some proteins generally involved in stress adaptation also appeared to be affected during the stationary phase of growth. It was especially the case for ferritin which is a homohexamer in L. monocytogenes [8] able to oxidize and sequester about 500 iron atoms. The induction of ferritin in stationary phase has been previously reported [49] but here we show that at least two of the five spots of ferritin increased whereas one decreased in the stationary phase. This protein has also been characterized as a stress protein induced by cold-shock [8], heat-shock, SDS, deoxycholate, or ethanol [50]. The respective involvement of the different molecules of ferritin appears quite difficult to explain and needs further investigation. Another stress protein, GroES, was found to be upregulated in stationary phase. This class I heat-shock protein is an ubiquitous bacterial chaperonin induced in numerous bacteria in response to various stresses such as heatshock, acid-shock, salt, ethanol, or hydrogen peroxyde. In this study, the induction of GroES could be an unrelated consequence of the transition to stationary phase. Indeed, the $\mathrm{pH}$ of $\mathrm{BHI}$ broth decreased from 7.5 to 5.5 during growth under our culture conditions. Therefore, as the induction of GroES following an acidic treatment has been already reported in L. monocytogenes [51], the higher level of expression observed in stationary phase could only be due to the medium acidification.

In some species, such as Clostridium difficile [52] or Streptococcus pyogenes [53], the virulence factors are differentially regulated according to the growth phase. For $L$. monocytogenes, it is known that inlA and inlB genes, encoding internalin proteins involved in the cellular internalization step of the virulence process, are maximally expressed during the exponential phase of growth [54]. However, the expression of the transcriptional activator PrfA, which positively regulates most of the virulence genes, increases during the stationary phase [55] and starvation [56]. Due to their 
extracellular or membraneous localization and/or to their basic $\mathrm{pl}$, these proteins could not have been found in our study. However, we observed that the level of expression of listeriolysin O precursor (LLO), which is under the control of PrfA, was increased in the stationary phase. The four spots surrounded in Fig. 3D were identified as LLO and all appeared overexpressed in the stationary phase. These spots most likely correspond to different levels of protein phosphorylation of LLO.

It is surprising to note that the level of expression of RpoZ, a probable DNA-RNA polymerase omega subunit [57, 58], increased in stationary phase. Little is known of $r p o Z$ regulation and its possible involvement in bacterial physiology except that an w-null mutant of $E$. coli exhibits a slowgrowth phenotype [59] and that the $\mathrm{YloH}$ gene encoding w subunit in Bacillus cereus is induced during heat stress response [60]. Therefore, the reason for the increase in $L$. monocytogenes RpoZ in the stationary phase of growth remains unclear and requires further investigation.

\section{Concluding remarks}

In summary, we have established a 2-DE database of the intracellular soluble proteins of $L$. monocytogenes EGDe by using three overlapping $\mathrm{pH}$ gradients. The annotated 2-DE reference maps with detailed information on the 201 identified spots can be found on our website at http://www.clermont.inra.fr/proteome. This first 2-DE database is an important tool for all further proteomic studies developed on biological events in L. monocytogenes strains. In this way, the comparative proteomic analysis between $L$. monocytogenes EGDe cells in midlog and stationary growth phases revealed some interesting results. A deepened characterization of the reprogramming of gene expression pattern in the stationary phase will be undertaken through a kinetic study with protein radiolabelling.

We are greatly indebted to $R$. Taylor for critical reading of the manuscript. This work was supported in part by a Fundamental Research Program in Microbiology, Infectious and Parasitology of the French Minister of National Education Research and Technology.

\section{References}

[1] Vazquez-Boland, J. A., Kuhn, M., Berche, P., Chakraborty, T. et al., Clin. Microbiol. Rev. 2001, 14, 584-640.

[2] Cheroutre-Vialette, M., Lebert, I., Hébraud, M., Labadie, J., Lebert, A., Int. J. Food Microbiol. 1998, 42, 71-77.

[3] Vasseur, C., Baverel, L., Hébraud, M., Labadie, J., J. Appl. Microbiol. 1999, 8, 469-476.

[4] Vasseur, C., Rigaud, N., Hébraud, M., Labadie, J., J. Food Protect. 2001, 64, 1442-1445.
[5] Michel, V., Lehoux, I., Depret, G., Anglade, P. et al., J. Bacteriol. 1997, 179, 7331-7342.

[6] Vasseur, C., Labadie, J., Hébraud, M., Electrophoresis 1999, 20, 2204-2213.

[7] Perrot, F., Hébraud, M., Junter, G.-A., Jouenne, T., Electrophoresis 2000, 21, 1625-1629.

[8] Hébraud, M., Guzzo, J., FEMS Microbiol. Lett. 2000, 190, 19-34.

[9] Perrot, F., Hébraud, M., Charlionet, R., Junter, G.-A. et al., Electrophoresis 2000, 21, 645-653.

[10] Perrot, F., Hébraud, M., Junter, G.-A., Jouenne, T., Electrophoresis 2001, 22, 2110-2119.

[11] Chavant, P., Martinie, B., Meylheuc, T., Bellon-Fontaine, M. N. et al., Appl. Environ. Microbiol. 2002, 68, 728-737.

[12] Glaser, P., Frangeul, L., Buchrieser, C., Rusniok, C. et al., Science 2001, 294, 849-852.

[13] Golaz, O., Hughes, G. J., Frutiger, S., Paquet, N. et al., Electrophoresis 1993, 14, 1223-1231.

[14] Karlsson, K., Cairns, N., Lubec, G., Fountoulakis, M., Electrophoresis 1999, 20, 2970-2976.

[15] Corbett, J. M., Why, H. J., Wheeler, C. H., Richardson, P. J. et al., Electrophoresis 1998, 19, 2031-2042.

[16] Büttner, K., Bernhardt, J., Scharf, C., Schmid, R. et al., Electrophoresis 2001, 22, 2908-2935.

[17] Tonella, L., Walsh, B. J., Sanchez, J. C., Ou, K. et al., Electrophoresis 1998, 19, 1960-1971.

[18] Langen, H., Takacs, B., Evers, S., Berndt, P. et al., Electrophoresis 2000, 21, 411-429.

[19] Perrin, C., Gonzalez-Marquez, H., Gaillard, J. L., Bracquart, P. et al., Electrophoresis 2000, 21, 949-955.

[20] Rosenkrands, I., Electrophoresis 2000, 21, 935-948.

[21] Hermann, T., Electrophoresis 2001, 22, 1712-1723.

[22] Wildgruber, R., Harder, A., Obermaier, C., Boguth, G. et al., Electrophoresis 2000, 21, 2610-2616.

[23] Bradford, M. M., Anal.Biochem. 1976, 72, 248-254.

[24] O’Farrell, P. H., J. Biol. Chem. 1975, 250, 4007-4021.

[25] Rabilloud, T., Electrophoresis 1992, 13, 429-439.

[26] Blum, H., Beier, H., Gross, H. J., Electrophoresis 1987, 8, 93-99.

[27] Neuhoff, V., Arold, N., Taube, D., Ehrhardt, W., Electrophoresis 1988, 9, 255-262.

[28] VanBogelen, R. A., Abshire, K. Z., Moldover, B., Olson, E. R. et al., Electrophoresis 1997, 18, 1243-1251.

[29] Rabilloud, T., Adessi, C., Giraudel, A., Lunardi, J., Electrophoresis 1997, 18, 307-316.

[30] Herbert, B. R., Molloy, M. P., Gooley, A. A., Walsh, B. J. et al., Electrophoresis 1998, 19, 845-851.

[31] Siegele, D. A., Kolter, R., J. Bacteriol. 1992, 174, 345-348.

[32] Ishihama, A., Curr. Opin. Genet. Dev. 1997, 7, 582-588.

[33] Chatterji, D., Ojha, A. K., Curr. Opin. Microbiol. 2001, 4, 160165.

[34] Godfrey, H. P., Bugrysheva, J. V., Cabello, F. C., Trends Microbiol. 2002, 10, 349-351.

[35] Lange, R., Hengge-Aronis, R., Mol. Microbiol. 1991, 5, 4959.

[36] Hecker, M., Völker, U., Mol. Microbiol. 1998, 29, 1129-1136.

[37] Ferreira, A., O’Byrne, C. P., Boor, K. J., Appl. Environ. Microbiol. 2001, 67, 4454-4457.

[38] Becker, L. A., Cetin, M. S., Hutkins, R. W., Benson, A. K., J. Bacteriol. 1998, 180, 4547-4554.

[39] Petersohn, A., Brigulla, M., Haas, S., Hoheisel, J. D. et al., J. Bacteriol. 2001, 183, 5617-5631. 
[40] Kazmierczak, M. J., Mithoe, S. C., Boor, K. J., Wiedmann, M., J. Bacteriol. 2003, 185, 5722-5734.

[41] Milohanic, E., Glaser, P., Coppée, J.-Y., Frangeul, L. et al., Mol. Microbiol. 2003, 47, 1613-1625.

[42] Milner, M. G., Saunders, J. R., McCarthy, A. J., Microbiology 2001, 147, 2689-2696.

[43] Chang, D. E., Smalley, D. J., Conway, T., Mol. Microbiol. 2002, 45, 289-306.

[44] Blanco, G., Rodicio, M. R., Puglia, A. M., Mendez, C. et al., Mol. Microbiol. 1994, 12, 375-385.

[45] Kaan, T., Homuth, G., Mader, U., Bandow, J. et al., Microbiology 2002, 148, 3441-3455.

[46] Davis, B. D., Luger, S. M., Tai, P. C., J. Bacteriol. 1986, 166, 439-445.

[47] Switzer, R. L., Turner, R. J., Lu, Y., Prog. Nucleic Acid Res. Mol. Biol. 1999, 62, 329-367.

[48] Maas, W. K., Microbiol. Rev. 1994, 58, 631-640.

[49] Polidoro, M., De Biase, D., Montagnini, B., Guarrera, L. et al., Gene 2002, 296, 121.

[50] Phan-Thanh, L., Gormon, T., Electrophoresis 1997, 18, 1464-1471.
[51] Gahan, C. G., O’Mahony, J., Hill, C., Infect. Immun. 2001, 69, 3924-3932.

[52] Dupuy, B., Sonenshein, A. L., Mol. Microbiol. 1998, 27, 107120.

[53] Unnikrishnan, M., Cohen, J., Sriskandan, S., Infect. Immun. 1999, 67, 5495-5499.

[54] Dramsi, S., Kocks, C., Forestier, C., Cossart, P., Mol. Microbiol. 1993, 9, 931-941.

[55] Mengaud, J., Dramsi, S., Gouin, E., Vazquez-Boland, J. A. et al., Mol. Microbiol. 1991, 5, 2273-2283.

[56] Sokolovic, Z., Schuller, S., Bohne, J., Baur, A. et al., Infect. Immun. 1996, 64, 4008-4019.

[57] Kojima, I., Kasuga, K., Kobayashi, M., Fukasawa, A. et al., J. Bacteriol. 2002, 184, 6417-6423.

[58] Gentry, D. R., Burgess, R. R., J. Bacteriol. 1989, 171, 1271 1277.

[59] Mukherjee, K., Nagai, H., Shimamoto, N., Chatterji, D., Eur. J. Biochem. 1999, 266, 228-235.

[60] Periago, P. M., Van Schaik, W., Abee, T., Wouters, J. A., Appl. Envir. Microbiol. 2002, 68, 3486-3495.

\section{Addendum}

Table 1. List of L. monocytogenes EGDe soluble proteins localized on the 2-DE maps

\begin{tabular}{|c|c|c|c|c|c|c|c|c|c|c|c|}
\hline $\begin{array}{l}\text { (Map local- } \\
\text { ization) } \\
\text { Spot No. }\end{array}$ & $\begin{array}{l}\text { Gene } \\
\text { name }\end{array}$ & Protein description & $\begin{array}{l}\text { Func- } \\
\text { tional } \\
\text { category }\end{array}$ & $\begin{array}{l}\mathrm{NCBI} \\
\text { protein } \\
\text { accession }\end{array}$ & $\begin{array}{l}\text { Swiss-Prot } \\
\text { protein } \\
\text { accession }\end{array}$ & $\begin{array}{l}M_{\mathrm{r}}(\mathrm{k} \\
\text { (obs) }\end{array}$ & $\begin{array}{l}\mathrm{kDa}) \\
\text { (calc) }\end{array}$ & (obs) & pl & $\begin{array}{l}\text { Peptides } \\
\text { matched }\end{array}$ & $\begin{array}{l}\text { Cover- } \\
\text { age } \\
(\%)\end{array}$ \\
\hline (b2)48 & $d d I A$ & D-Alanine-D-alanine ligase & 1.1 & $\mathrm{gi} / 16802896$ & LM00855 & 45.3 & 40.7 & 4.7 & 4.20 & 3 & 7 \\
\hline (d2)15 & Imo0096 & $\begin{array}{l}\text { Similar to PTS system mannose- } \\
\text { specific, factor IIAB }\end{array}$ & 1.2 & $\mathrm{gi} / 16802144$ & LM00096 & 38.9 & 34.9 & 5.3 & 5.15 & 9 & 25 \\
\hline (d4)38 & Imo0783 & $\begin{array}{l}\text { Similar to mannose-specific } \\
\text { phosphotransferase system } \\
\text { (PTS) component IIB }\end{array}$ & 1.2 & $\mathrm{gi} / 16802825$ & LM00783 & 19.9 & 17.9 & 6.2 & 6.55 & 10 & 45 \\
\hline (b5)52 & ptsH & $\begin{array}{l}\text { PTS phosphocarrier protein Hpr } \\
\text { (histidine containing protein) }\end{array}$ & 1.2 & $\mathrm{gi} / 16803042$ & LM01002 & 10.9 & 9.4 & 4.7 & 4.46 & 5 & 43 \\
\hline (c4)50 & Imo1017 & $\begin{array}{l}\text { Similar to phosphotransferase } \\
\text { system glucose-specific } \\
\text { enzyme IIA }\end{array}$ & 1.2 & $\mathrm{gi} / 16803057$ & LM01017 & 20.9 & 17.6 & 5.1 & 5.02 & 4 & 37 \\
\hline (b3)11 & Imo2415 & $\begin{array}{l}\text { Similar to ABC transporter, } \\
\text { ATP-binding protein }\end{array}$ & 1.2 & $\mathrm{gi} / 16804453$ & LM02415 & 33.1 & 29.1 & 4.6 & 4.27 & 5 & 22 \\
\hline (f5) 79 & Imo0399 & $\begin{array}{l}\text { Similar to fructose-specific } \\
\text { phosphotransferase enzyme } \\
\text { IIB }\end{array}$ & 1.2 & $\mathrm{gi} / 16802444$ & LM00399 & 13.3 & 11.3 & 7.8 & 8.23 & 3 & 21 \\
\hline (d3)90 & Imo1636 & $\begin{array}{l}\text { Similar to similar to ABC } \\
\text { transporter (ATP-binding } \\
\text { protein) }\end{array}$ & 1.2 & $\mathrm{gi} / 16803676$ & LM01636 & 33.3 & 33.8 & 6.3 & 6.52 & 4 & 12 \\
\hline (b1)99 & Imo1003 & $\begin{array}{l}\text { Phosphotransferase system } \\
\text { enzyme I }\end{array}$ & 1.2 & $\mathrm{gi} / 16803043$ & LM01003 & 67.9 & 63.2 & 4.6 & 4.44 & 11 & 12 \\
\hline (e2)122 & gbuA & $\begin{array}{l}\text { Highly similar to glycine betaine } \\
\text { ABC transporter (ATP-binding } \\
\text { protein) }\end{array}$ & 1.2 & $\mathrm{gi} / 16803054$ & LM01014 & 46.7 & 43.6 & 6.3 & 6.40 & 9 & 28 \\
\hline
\end{tabular}


Table 1. Continued

\begin{tabular}{|c|c|c|c|c|c|c|c|c|c|c|c|}
\hline $\begin{array}{l}\text { (Map local- } \\
\text { ization) } \\
\text { Spot No. }\end{array}$ & $\begin{array}{l}\text { Gene } \\
\text { name }\end{array}$ & Protein description & $\begin{array}{l}\text { Functional } \\
\text { category }\end{array}$ & $\begin{array}{l}\mathrm{NCBI} \\
\text { protein } \\
\text { accession }\end{array}$ & $\begin{array}{l}\text { Swiss-Prot } \\
\text { protein } \\
\text { accession }\end{array}$ & $\begin{aligned} & M_{\mathrm{r}}(\mathrm{K} \\
& \text { (obs) }\end{aligned}$ & & (obs) & (calc) & $\begin{array}{l}\text { Peptides } \\
\text { matched }\end{array}$ & $\begin{array}{l}\text { Cover- } \\
\text { age } \\
(\%)\end{array}$ \\
\hline (b2)68 & atpD & $\begin{array}{l}\text { Highly similar to } \mathrm{H}^{+} \text {-transporting } \\
\text { ATP synthase chain beta }\end{array}$ & 1.4 & gi/16804567 & LM02529 & 53.3 & 51.6 & 4.7 & 4.47 & 18 & 32 \\
\hline (d2)83 & atpA & $\begin{array}{l}\text { Highly similar to } \mathrm{H}^{+} \text {-transporting } \\
\text { ATP synthase chain alpha }\end{array}$ & 1.4 & gi/16804569 & LM02531 & 56.3 & 55.1 & 5.4 & 5.17 & 11 & 24 \\
\hline (f3)93 & atpH & $\begin{array}{l}\text { Highly similar to } \mathrm{H}^{+} \text {-transporting } \\
\text { ATP synthase chain delta }\end{array}$ & 1.4 & gi/16804570 & LM02532 & 25.9 & 20.3 & 7.8 & 8.75 & 8 & 47 \\
\hline (b2)49 & $\operatorname{trx} B$ & Thioredoxin reductase & 1.4 & gi/16804516 & LM02478 & 37.3 & 34.2 & 4.7 & 4.52 & 10 & 32 \\
\hline (e2)123 & Imo2471 & Similar to NADH oxidase & 1.4 & gi/16804509 & LM02471 & 42.4 & 37.0 & 6.4 & 6.87 & 6 & 22 \\
\hline (b3)7 & flaA & Flagellin protein & 1.5 & gi/16802732 & LM00690 & 33.6 & 30.4 & 4.7 & 4.67 & 13 & 48 \\
\hline (b5)32 & Imo0197 & $\begin{array}{l}\text { Similar to } B \text {. subtilis SpoVG } \\
\text { protein }\end{array}$ & 1.7 & gi/16802243 & LM00197 & 12.5 & 11.4 & 4.6 & 4.24 & 4 & 35 \\
\hline (b5)69 & Imo0196 & $\begin{array}{l}\text { Similar to } B \text {. subtilis SpoVG } \\
\text { protein }\end{array}$ & 1.7 & gi/16802242 & LM00196 & 13.2 & 11.2 & 4.5 & 4.20 & 7 & 47 \\
\hline (b2)82 & $\mathrm{ftsZ}$ & $\begin{array}{l}\text { Highly similar to cell-division } \\
\text { initiation protein FtsZ }\end{array}$ & 1.7 & gi/16804071 & LM02032 & 47.7 & 41.3 & 4.8 & 4.48 & 10 & 30 \\
\hline (b4)102 & div IVA & $\begin{array}{l}\text { Similar to cell division initiation } \\
\text { protein (septum placement) }\end{array}$ & 1.7 & gi/16804059 & LM02020 & 23.6 & 20.3 & 4.7 & 4.48 & 8 & 45 \\
\hline (d3)92 & Imo1086 & $\begin{array}{l}\text { Similar to CDP-ribitol } \\
\text { pyrophosphorylase }\end{array}$ & 2.1 & gi/16803126 & LM01086 & 31.0 & 26.7 & 6.0 & 5.96 & 13 & 50 \\
\hline (d2)12 & pfk & $\begin{array}{l}\text { Highly similar to } \\
\text { 6-phosphofructokinase }\end{array}$ & 2.1 .1 & gi/16803611 & LM01571 & 39.4 & 34.4 & 5.6 & 5.44 & 7 & 24 \\
\hline (e1)59 & glpD & $\begin{array}{l}\text { Similar to glycerol } 3 \text { phosphate } \\
\text { dehydrogenase }\end{array}$ & 2.1.1 & gi/16803333 & LM01293 & 66.3 & 63.2 & 6.4 & 6.77 & 14 & 29 \\
\hline (d2)28 & ackA & Highly similar to acetate kinase & 2.1.1 & gi/16803621 & LM01581 & 46.5 & 43.8 & 5.4 & 5.19 & 5 & 14 \\
\hline (c3)61 & Imo2696 & $\begin{array}{l}\text { Similar to hypothetical } \\
\text { dihydroxyacetone kinase }\end{array}$ & 2.1.1 & gi/16804733 & LM02696 & 25.9 & 21.5 & 5.1 & 4.96 & 7 & 27 \\
\hline (d2) 16 & Idh & $\begin{array}{l}\text { Similar to L-lactate } \\
\text { dehydrogenase }\end{array}$ & 2.1 .1 & gi/16802256 & LM00210 & 38.0 & 34.2 & 5.3 & 5.05 & 6 & 16 \\
\hline (d3)56 & $f b a A$ & $\begin{array}{l}\text { Similar to fructose-1,6-bis- } \\
\text { phosphate aldolase }\end{array}$ & 2.1 .1 & gi/16804594 & LM02556 & 33.1 & 30.1 & 5.2 & 5.05 & 16 & 59 \\
\hline (c3)100 & Imo2592 & $\begin{array}{l}\text { Similar to oxydoreductase, } \\
\text { aldo-keto reductase family }\end{array}$ & 2.1.1 & gi/16804630 & LM02592 & 32.5 & 31.5 & 5.2 & 4.95 & 12 & 34 \\
\hline (c3)104 & Imo2743 & Similar to transaldolase & 2.1 .1 & gi/16804780 & LM02743 & 28.0 & 23.1 & 4.9 & 4.73 & 11 & 49 \\
\hline (d3)118 & Imo2700 & Similar to aldo/keto reductase & 2.1.1 & gi/16804737 & LM02700 & 34.1 & 32.6 & 6.1 & 6.15 & 10 & 44 \\
\hline (d1/e1)129 & Imo0913 & $\begin{array}{l}\text { Similar to succinate semial- } \\
\text { dehyde dehydrogenase }\end{array}$ & 2.1 .1 & gi/16802954 & LM00913 & 60.3 & 53.2 & 5.9 & 5.87 & 13 & 27 \\
\hline (b2)13 & $p d h B$ & $\begin{array}{l}\text { Highly similar to pyruvate } \\
\text { dehydrogenase (E1 beta } \\
\text { subunit) }\end{array}$ & 2.1 .2 & gi/16803093 & LM01053 & 41.5 & 35.3 & 4.8 & 4.51 & 9 & 27 \\
\hline (c1)22 & pgm & $\begin{array}{l}\text { Highly similar to phospho- } \\
\text { glycerate mutase }\end{array}$ & 2.1 .2 & gi/16804494 & LM02456 & 62.0 & 56.1 & 5.1 & 4.89 & 9 & 27 \\
\hline (c2)10 & gap & $\begin{array}{l}\text { Highly similar to glyceraldehyde } \\
\text { 3-phosphate dehydrogenase }\end{array}$ & 2.1 .2 & gi/16804497 & LM02459 & 43.8 & 36.3 & 5.3 & 5.00 & 6 & 11 \\
\hline (c2)31 & $p d h D$ & $\begin{array}{l}\text { Highly similar to dihydroli- } \\
\text { poamide dehydrogenase, } \\
\text { E3 subunit of pyruvate } \\
\text { dehydrogenase complex }\end{array}$ & 2.1 .2 & gi/16803095 & LM01055 & 58.4 & 49.5 & 5.2 & 5.01 & 6 & 24 \\
\hline
\end{tabular}


Table 1. Continued

\begin{tabular}{|c|c|c|c|c|c|c|c|c|c|c|c|}
\hline $\begin{array}{l}\text { (Map local- } \\
\text { ization) } \\
\text { Spot No. }\end{array}$ & $\begin{array}{l}\text { Gene } \\
\text { name }\end{array}$ & Protein description & $\begin{array}{l}\text { Functional } \\
\text { category }\end{array}$ & $\begin{array}{l}\mathrm{NCBI} \\
\text { protein } \\
\text { accession }\end{array}$ & $\begin{array}{l}\text { Swiss-Prot } \\
\text { protein } \\
\text { accession }\end{array}$ & $\begin{aligned} & M_{\mathrm{r}}(\mathrm{r} \\
& \text { (obs) }\end{aligned}$ & & (obs) & (calc) & $\begin{array}{l}\text { Peptides } \\
\text { matched }\end{array}$ & $\begin{array}{l}\text { Cover- } \\
\text { age } \\
(\%)\end{array}$ \\
\hline (d2)86 & $p d h A$ & $\begin{array}{l}\text { highly similar to pyruvate dehy- } \\
\text { drogenase (E1 alpha subunit) }\end{array}$ & 2.1 .2 & gi/16803092 & LM01052 & 45.0 & 41.3 & 6.1 & 6.42 & 17 & 48 \\
\hline (b2)72 & eno & Highly similar to enolase & 2.1 .2 & gi/16804493 & LM02455 & 47.3 & 46.5 & 4.7 & 4.42 & 22 & 66 \\
\hline (c2)74 & pgk & $\begin{array}{l}\text { Highly similar to phospho- } \\
\text { glycerate kinase }\end{array}$ & 2.1 .2 & gi/16804496 & LM02458 & 46.0 & 42.1 & 4.9 & 4.72 & 9 & 30 \\
\hline (b3)103 & tpi & $\begin{array}{l}\text { Highly similar to triose } \\
\text { phosphate isomerase }\end{array}$ & 2.1 .2 & gi/16804495 & LM02457 & 29.1 & 26.9 & 4.7 & 4.46 & 7 & 25 \\
\hline (c2)132 & pgi & $\begin{array}{l}\text { Glucose-6-phosphate } \\
\text { isomerase }\end{array}$ & 2.1 .2 & gi/16804405 & LM02367 & 52.6 & 49.9 & 5.2 & 5.07 & 20 & 47 \\
\hline (d2)66 & Imo2414 & Similar to aminotransferase & 2.2 & gi/16804452 & LM02414 & 49.9 & 48.1 & 5.9 & 5.79 & 15 & 36 \\
\hline (d3)9 & cysk & $\begin{array}{l}\text { Highly similar to cysteine } \\
\text { synthase }\end{array}$ & 2.2 & gi/16802269 & LM00223 & 36.0 & 32.2 & 5.3 & 5.08 & 7 & 21 \\
\hline (c2)58 & Imo0265 & $\begin{array}{l}\text { Similar to succinyldiaminopime- } \\
\text { late desuccinylase }\end{array}$ & 2.2 & gi/16802311 & LM00265 & 45.3 & 41.9 & 5.1 & 4.71 & 6 & 24 \\
\hline (d2)33 & Imo1611 & Similar to aminopeptidase & 2.2 & gi/16803651 & LM01611 & 42.7 & 38.8 & 5.8 & 5.66 & 8 & 29 \\
\hline (c2)30 & Imo1579 & $\begin{array}{l}\text { Similar to alanine } \\
\text { dehydrogenase }\end{array}$ & 2.2 & gi/16803619 & LM01579 & 44.7 & 39.6 & 5.2 & 5.08 & 13 & 43 \\
\hline (c2)75 & Imo1620 & Similar to Xaa-His dipeptidase & 2.2 & gi/16803660 & LM01620 & 53.2 & 51.8 & 4.9 & 4.71 & 15 & 45 \\
\hline (c3)89 & Imo1011 & $\begin{array}{l}\text { Similar to tetrahydrodipicolinate } \\
\text { succinylase }\end{array}$ & 2.2 & gi/16803051 & LM01011 & 30.6 & 24.8 & 5.5 & 4.70 & 9 & 33 \\
\hline (d2)108 & Imo1437 & $\begin{array}{l}\text { Similar to aspartate-semi- } \\
\text { aldehyde dehydrogenase }\end{array}$ & 2.2 & gi/16803477 & LM01437 & 46.7 & 37.6 & 5.5 & 5.29 & 8 & 15 \\
\hline (d2)5 & guaB & $\begin{array}{l}\text { Similar to inosine-mono- } \\
\text { phosphate dehydrogenase }\end{array}$ & 2.3 & gi/16804795 & LM02758 & 58.4 & 52.5 & 6.1 & 6.45 & 13 & 30 \\
\hline (b3)60 & $d e o D$ & $\begin{array}{l}\text { Purine nucleoside } \\
\text { phosphorylase }\end{array}$ & 2.3 & gi/16803896 & LM01856 & 27.0 & 29.5 & 4.8 & 4.86 & 8 & 43 \\
\hline (b2)65 & $d r m$ & Similar to phosphopentomutase & 2.3 & gi/16803993 & LM01954 & 50.4 & 43.7 & 4.8 & 4.84 & 12 & 43 \\
\hline (d4)67 & purE & $\begin{array}{l}\text { Phosphoribosylaminoimidazole } \\
\text { carboxylase I }\end{array}$ & 2.3 & gi/16803815 & LM01775 & 20.4 & 16.9 & 5.5 & 5.21 & 6 & 49 \\
\hline (b2)81 & $p d p$ & $\begin{array}{l}\text { Similar to pyrimidine-nucleoside } \\
\text { phosphorylase }\end{array}$ & 2.3 & gi/16804032 & LM01993 & 49.4 & 46.1 & 4.8 & 4.50 & 13 & 32 \\
\hline (d3)128 & $d r a$ & $\begin{array}{l}\text { Similar to deoxyribose- } \\
\text { phosphate aldolase }\end{array}$ & 2.3 & gi/16804034 & LM01995 & 28.2 & 23.5 & 5.5 & 5.02 & 6 & 31 \\
\hline (c4)134 & $n d k$ & $\begin{array}{l}\text { Similar to nucleoside } \\
\text { diphosphate kinase }\end{array}$ & 2.3 & gi/16803968 & LM01929 & 16.9 & 16.5 & 5.1 & 5.02 & 8 & 63 \\
\hline (c2)35 & Imo1372 & $\begin{array}{l}\text { Similar to branched-chain } \\
\text { alpha-keto acid dehydrog- } \\
\text { enase E1 subunit } \\
\text { (2-0xoisovalerate dehydrog- } \\
\text { enase alpha subunit) }\end{array}$ & 2.4 & gi/16803412 & LM01372 & 42.7 & 36.3 & 4.8 & 4.54 & 9 & 25 \\
\hline (b2)64 & Imo1373 & $\begin{array}{l}\text { Similar to branched-chain } \\
\text { alpha-keto acid dehydrog- } \\
\text { enase E1 subunit } \\
\text { (2-0xoisovalerate dehydrog- } \\
\text { enase beta subunit) }\end{array}$ & 2.4 & gi/16803413 & LM01373 & 38.9 & 35.7 & 4.8 & 4.55 & 7 & 35 \\
\hline (b3)117 & Imo2829 & $\begin{array}{l}\text { Similar to yeast protein Frm2p } \\
\text { involved in fatty acid } \\
\text { signaling }\end{array}$ & 2.4 & gi/16804866 & LM02829 & 26.6 & 22.2 & 4.7 & 4.44 & 11 & 49 \\
\hline
\end{tabular}


Table 1. Continued

\begin{tabular}{|c|c|c|c|c|c|c|c|c|c|c|c|}
\hline $\begin{array}{l}\text { (Map local- } \\
\text { ization) } \\
\text { Spot No. }\end{array}$ & $\begin{array}{l}\text { Gene } \\
\text { name }\end{array}$ & Protein description & $\begin{array}{l}\text { Functional } \\
\text { category }\end{array}$ & $\begin{array}{l}\mathrm{NCBI} \\
\text { protein } \\
\text { accession }\end{array}$ & $\begin{array}{l}\text { Swiss-Prot } \\
\text { protein } \\
\text { accession }\end{array}$ & $\begin{aligned} & M_{\mathrm{r}}(\mathrm{r} \\
& \text { (obs) }\end{aligned}$ & & (obs) & (calc) & $\begin{array}{l}\text { Peptides } \\
\text { matched }\end{array}$ & $\begin{array}{l}\text { Cover- } \\
\text { age } \\
(\%)\end{array}$ \\
\hline (c2)124 & Imo0931 & $\begin{array}{l}\text { Similar to lipoate protein } \\
\text { igase } \mathrm{A}\end{array}$ & 2.4 & gi/16802971 & LM00931 & 43.3 & 37.9 & 5.0 & 4.74 & 11 & 21 \\
\hline (d3)20 & Imo0786 & $\begin{array}{l}\text { Similar to acyl-carrier protein } \\
\text { phosphodiesterase and to } \\
\text { NAD(P)H dehydrogenase }\end{array}$ & 2.5 & gi/16802828 & LM00786 & 28.6 & 23.1 & 5.3 & 5.08 & 7 & 20 \\
\hline (e3)46 & Imo1336 & $\begin{array}{l}\text { Similar to 5-formyltetrahydro- } \\
\text { folate cyclo-ligase }\end{array}$ & 2.5 & gi/16803376 & LM01336 & 26.5 & 20.7 & 7.1 & 7.18 & 4 & 20 \\
\hline (c2/d2)14 & Imo2101 & $\begin{array}{l}\text { Similar to a protein required } \\
\text { for pyridoxine synthesis }\end{array}$ & 2.5 & gi/16804140 & LM02101 & 37.8 & 31.7 & 5.1 & 5.12 & 11 & 18 \\
\hline (c2)84 & recA & Recombination protein recA & 3.3 & gi/16803438 & LM01398 & 44.5 & 37.9 & 5.1 & 4.81 & 10 & 23 \\
\hline (f2)37 & $\operatorname{par} B$ & Partition protein ParB homolog & 3.4 & gi/16804827 & LM02790 & 37.4 & 32.2 & 7.8 & 8.74 & 8 & 21 \\
\hline (c4)63 & Imo1367 & Similar to arginine repressor & 3.5 .2 & gi/16803407 & LM01367 & 15.6 & 16.8 & 5.0 & 5.24 & 2 & 26 \\
\hline (e3)40 & pyrR & $\begin{array}{l}\text { Highly similar to pyrimidine } \\
\text { operon regulatory protein }\end{array}$ & 3.5 .2 & gi/16803880 & LM01840 & 27.2 & 20.5 & 6.5 & 6.69 & 4 & 15 \\
\hline$(d 4) 78$ & fur & $\begin{array}{l}\text { Similar to transcriptional } \\
\text { regulator (Fur family) }\end{array}$ & 3.5 .2 & gi/16803995 & LM01956 & 21.5 & 17.3 & 6.2 & 6.40 & 5 & 45 \\
\hline (d2)85 & $\operatorname{ccpA}$ & Catabolite control protein A & 3.5 .2 & gi/16803639 & LM01599 & 42.6 & 36.9 & 5.45 & 5.05 & 11 & 32 \\
\hline (c3)101 & $\operatorname{cod} Y$ & $\begin{array}{l}\text { Highly similar to B. subtilis } \\
\text { Cod Y protein }\end{array}$ & 3.5 .2 & gi/16803320 & LM01280 & 31.9 & 28.7 & 4.9 & 4.60 & 11 & 35 \\
\hline (b4)24 & Imo1496 & $\begin{array}{l}\text { Similar to transcription } \\
\text { elongation factor GreA }\end{array}$ & 3.5 .3 & gi/16803536 & LM01496 & 22.8 & 17.5 & 4.6 & 4.31 & 5 & 41 \\
\hline (c2)8 & tsf & Translation elongation factor & 3.5 .3 & gi/16803697 & LM01657 & 41.6 & 32.6 & 5.1 & 4.85 & 14 & 36 \\
\hline (b2)76 & rрoA & $\begin{array}{l}\text { Highly similar to RNA } \\
\text { polymerase (alpha subunit) }\end{array}$ & 3.5 .3 & gi/16804644 & LM02606 & 44.0 & 34.9 & 4.8 & 4.53 & 8 & 21 \\
\hline (d2)29 & fmt & $\begin{array}{l}\text { Similar to methionyl-tRNA } \\
\text { formyltransferase }\end{array}$ & 3.6 & gi/16803863 & LM01823 & 41.4 & 34.1 & 5.6 & 5.26 & 5 & 22 \\
\hline (b5)27 & $r p / L$ & Ribosomal protein L12 & 3.7 .1 & gi/16802297 & LM00251 & 10.5 & 12.5 & 4.5 & 4.23 & 7 & 49 \\
\hline (c5)25 & $r p s F$ & Ribosomal protein S6 & 3.7 .1 & gi/16802092 & LM00044 & 8.8 & 11.5 & 5.0 & 4.83 & 4 & 34 \\
\hline (b2)2 & Imo1938 & $\begin{array}{l}\text { Similar to similar to ribosomal } \\
\text { protein } \mathrm{S} 1 \text { like protein }\end{array}$ & 3.7 .1 & gi/16803977 & LM01938 & 49.4 & 41.4 & 4.5 & 4.21 & 7 & 20 \\
\hline (f5) 42 & rpmE & Ribosomal protein L31 & 3.7 .1 & gi/16804586 & LM02548 & 9.7 & 9.2 & 7.8 & 9.45 & 4 & 33 \\
\hline (d4)88 & rplJ & Ribosomal protein L10 & 3.7 .1 & gi/16802296 & LM00250 & 22.2 & 17.7 & 5.3 & 5.09 & 8 & 37 \\
\hline (d2)127 & $r p s B$ & 30 S ribosomal protein S2 & 3.7 .1 & gi/16803698 & LM01658 & 36.4 & 28.4 & 6.0 & 6.08 & 14 & 36 \\
\hline (e5)137 & $\operatorname{infA}$ & $\begin{array}{l}\text { Highly similar to initiation } \\
\text { factor IF-I }\end{array}$ & 3.7 .3 & gi/16804648 & LM02610 & 8.9 & 8.2 & 7.5 & 7.69 & 3 & 31 \\
\hline (c2)73 & tufA & $\begin{array}{l}\text { Highly similar to translation } \\
\text { elongation factor EF-Tu }\end{array}$ & 3.7 .4 & gi/16804690 & LM02653 & 47.7 & 43.3 & 4.9 & 4.55 & 27 & 73 \\
\hline (c3)18 & frr & $\begin{array}{l}\text { Highly similar to ribosome } \\
\text { recycling factors }\end{array}$ & 3.7 .5 & gi/16803354 & LM01314 & 25.9 & 20.7 & 5.2 & 4.95 & 13 & 62 \\
\hline (c4)135 & Imo1051 & $\begin{array}{l}\text { Similar to formylmethionine } \\
\text { deformylase and to } B \text {. subtilis } \\
\text { YkrB protein }\end{array}$ & 3.8 & gi/16803091 & LM01051 & 24.0 & 20.6 & 5.1 & 4.94 & 7 & 40 \\
\hline (b1)47 & tig & Trigger factor (prolyl isomerase) & 3.9 & gi/16803307 & LM01267 & 60.3 & 47.8 & 4.6 & 4.20 & 12 & 22 \\
\hline (b1)1 & dnak & $\begin{array}{l}\text { Class I heat-shock protein } \\
\text { (molecular chaperone) DnaK }\end{array}$ & 3.9 & gi/16803513 & LM01473 & 69.9 & 66.1 & 4.6 & 4.30 & 24 & 28 \\
\hline (b5)26 & groES & $\begin{array}{l}\text { Class I heat-shock protein } \\
\text { (chaperonin) GroES }\end{array}$ & 3.9 & gi/16804108 & LM02069 & 8.9 & 10.1 & 4.6 & 4.31 & 5 & 61 \\
\hline
\end{tabular}


Table 1. Continued

\begin{tabular}{|c|c|c|c|c|c|c|c|c|c|c|c|}
\hline $\begin{array}{l}\text { (Map local- } \\
\text { ization) } \\
\text { Spot No. }\end{array}$ & $\begin{array}{l}\text { Gene } \\
\text { name }\end{array}$ & Protein description & $\begin{array}{l}\text { Functional } \\
\text { category }\end{array}$ & $\begin{array}{l}\mathrm{NCBI} \\
\text { protein } \\
\text { accession }\end{array}$ & $\begin{array}{l}\text { Swiss-Prot } \\
\text { protein } \\
\text { accession }\end{array}$ & $\begin{aligned} & M_{\mathrm{r}}(\mathrm{r} \\
& \text { (obs) }\end{aligned}$ & $\begin{array}{l}\text { (kDa) } \\
\text { (calc) }\end{array}$ & (obs) & (calc) & $\begin{array}{l}\text { Peptides } \\
\text { matched }\end{array}$ & $\begin{array}{l}\text { Cover- } \\
\text { age } \\
(\%)\end{array}$ \\
\hline (b1)71 & groEL & $\begin{array}{l}\text { Class I heat-shock protein } \\
\text { (chaperonin) GroEL }\end{array}$ & 3.9 & gi/16804107 & LM02068 & 65.1 & 57.4 & 4.7 & 4.43 & 14 & 37 \\
\hline (b3)17 & ctc & $\begin{array}{l}\text { Similar to } B \text {. subtilis general } \\
\text { stress protein }\end{array}$ & 4.1 & gi/16802257 & LM00211 & 30.6 & 22.6 & 4.5 & 4.14 & 7 & 46 \\
\hline$(b 4 / c 4) 3$ & fri & Non-heme iron-binding ferritin & 4.1 & gi/16802983 & LM00943 & 19.6 & 18.0 & 4.9 & 4.57 & 7 & 58 \\
\hline (c3) 19 & Imo1138 & $\begin{array}{l}\text { Similar to ATP-dependent CIp } \\
\text { protease proteolytic } \\
\text { component }\end{array}$ & 4.1 & gi/16803178 & LM01138 & 26.4 & 21.3 & 4.9 & 4.71 & 7 & 36 \\
\hline (f4)36 & Imo1601 & Similar to general stress protein & 4.1 & gi/16803641 & LM01601 & 23.2 & 18.4 & 7.8 & 8.80 & 4 & 25 \\
\hline (c3)77 & $c l p P$ & $\begin{array}{l}\text { ATP-dependent Clp protease } \\
\text { proteolytic subunit }\end{array}$ & 4.1 & gi/16804506 & LM02468 & 25.9 & 21.6 & 4.9 & 4.71 & 13 & 33 \\
\hline (b3)87 & grpE & Heat shock protein GrpE & 4.1 & gi/16803514 & LM01474 & 29.4 & 21.9 & 4.7 & 4.25 & 6 & 33 \\
\hline (b4)114 & RsbW & $\begin{array}{l}\text { Sigma B activity negative } \\
\text { regulator RsbW }\end{array}$ & 4.1 & gi/16802935 & LM00894 & 21.7 & 17.5 & 4.6 & 4.22 & 12 & 70 \\
\hline (b5)121 & $\operatorname{csp} B$ & $\begin{array}{l}\text { Similar to major cold-shock } \\
\text { protein }\end{array}$ & 4.1 & gi/16804055 & LM02016 & 8.2 & 7.3 & 4.5 & 4.15 & 3 & 28 \\
\hline (c3)23 & sod & Superoxide dismutase & 4.2 & gi/16803479 & LM01439 & 26.5 & 22.6 & 5.2 & 5.10 & 6 & 33 \\
\hline$(c 4 / d 4) 131$ & Imo1583 & Similar to thiol peroxidases & 4.2 & gi/16803623 & LM01583 & 22.8 & 18.1 & 5.2 & 5.02 & 9 & 56 \\
\hline (d4)39 & Imo0127 & $\begin{array}{l}\text { Weakly similar to protein gp20 } \\
\text { from bacteriophage A118 }\end{array}$ & 4.3 & gi/16802175 & LM00127 & 23.5 & 19.7 & 6.3 & 6.52 & 4 & 28 \\
\hline (e2)4 & hly & Listeriolysin 0 precursor & 4.5 & gi/16802248 & LM00202 & 60.3 & 58.7 & 6.9 & 8.23 & 12 & 25 \\
\hline (d5)55 & Imo0903 & Conserved hypothetical protein & 5.2 & gi/16802944 & LM00903 & 12.8 & 13.9 & 5.3 & 5.17 & 3 & 41 \\
\hline (c3)21 & Imo2511 & $\begin{array}{l}\text { Similar to conserved hypo- } \\
\text { thetical proteins like to } \\
\text { B. subtilis YvyD protein }\end{array}$ & 5.2 & gi/16804549 & LM02511 & 25.0 & 21.6 & 5.2 & 5.03 & 4 & 19 \\
\hline (b5) 51 & Imo1028 & $\begin{array}{l}\text { Similar to B. subtilis YkzG } \\
\text { protein }\end{array}$ & 5.2 & gi/16803068 & LM01028 & 7.2 & 8.3 & 4.8 & 4.52 & 6 & 88 \\
\hline (e5)43 & Imo1058 & $\begin{array}{l}\text { Similar to } B \text {. subtilis YktA } \\
\text { protein }\end{array}$ & 5.2 & gi/16803098 & LM01058 & 9.7 & 10.4 & 6.3 & 6.86 & 4 & 31 \\
\hline (f5)41 & rpoZ & $\begin{array}{l}\text { Probable DNA-directed RNA } \\
\text { polymerase omega chain }\end{array}$ & 5.2 & gi/16803866 & LM01826 & 7.2 & 7.6 & 7.8 & 8.90 & 4 & 40 \\
\hline (b5)54 & Imo1888 & Similar to hypothetical proteins & 5.2 & gi/16803927 & LM01888 & 10.5 & 12.9 & 4.6 & 4.25 & 6 & 73 \\
\hline (d4)95 & Imo1515 & Similar to unknown protein & 5.2 & gi/16803555 & LM01515 & 17.0 & 15.6 & 5.7 & 5.26 & 8 & 61 \\
\hline$d(5) 97$ & Imo2426 & Conserved hypothetical proteins & 5.2 & gi/16804464 & LM02426 & 15.7 & 13.6 & 5.9 & 5.29 & 6 & 69 \\
\hline (e4)45 & Imo2021 & Similar to unknown protein & 5.2 & gi/16804060 & LM02021 & 24.2 & 19.1 & 6.9 & 7.18 & 8 & 34 \\
\hline (f3)34 & Imo2853 & $\begin{array}{l}\text { Highly similar to } B \text {. subtilis } \\
\text { Jag protein }\end{array}$ & 5.2 & gi/16804890 & LM02853 & 28.0 & 23.1 & 7.8 & 8.75 & 6 & 22 \\
\hline$(d 4) 70$ & Imo1468 & Similar to unknown proteins & 5.2 & gi/16803508 & LM01468 & 16.6 & 16.5 & 5.8 & 6.04 & 7 & 49 \\
\hline (c4)80 & Imo1580 & Similar to unknown protein & 5.2 & gi/16803620 & LM01580 & 16.6 & 16.9 & 4.9 & 4.72 & 5 & 25 \\
\hline (d3)91 & Imo2072 & $\begin{array}{l}\text { Similar to a putative DNA } \\
\text { binding proteins }\end{array}$ & 5.2 & gi/16804111 & LM02072 & 31.7 & 24.2 & 6.0 & 6.03 & 11 & 50 \\
\hline (c2)57 & Imo1726 & Similar to hypothetical proteins & 5.2 & gi/16803766 & LM01726 & 41.7 & 36.8 & 4.9 & 4.71 & 9 & 34 \\
\hline (d2)133 & Imo2487 & $\begin{array}{l}\text { Similar to B. subtilis YvIB } \\
\text { protein }\end{array}$ & 5.2 & gi/16804525 & LM02487 & 54.1 & 47.3 & 5.5 & 5.13 & 21 & 54 \\
\hline (d3)107 & Imo2256 & Similar to unknown protein & 5.2 & gi/16804295 & LM02256 & 24.2 & 19.1 & 5.3 & 5.04 & 12 & 61 \\
\hline (b5)109 & Imo2199 & Unknown protein & 5.2 & gi/16804238 & LM02199 & 11.4 & 14.5 & 4.6 & 4.52 & 8 & 47 \\
\hline
\end{tabular}


Table 1. Continued

\begin{tabular}{|c|c|c|c|c|c|c|c|c|c|c|c|}
\hline $\begin{array}{l}\text { (Map local- } \\
\text { ization) } \\
\text { Spot No. }\end{array}$ & $\begin{array}{l}\text { Gene } \\
\text { name }\end{array}$ & Protein description & $\begin{array}{l}\text { Functional } \\
\text { category }\end{array}$ & $\begin{array}{l}\mathrm{NCBI} \\
\text { protein } \\
\text { accession }\end{array}$ & $\begin{array}{l}\text { Swiss-Prot } \\
\text { protein } \\
\text { accession }\end{array}$ & $\begin{array}{r}M_{\mathrm{r}}(\mathrm{k} \\
\text { (obs) }\end{array}$ & kDa) & (obs) & ol & $\begin{array}{l}\text { Peptides } \\
\text { matched }\end{array}$ & $\begin{array}{l}\text { Cover- } \\
\text { age } \\
(\%)\end{array}$ \\
\hline (a5)110 & Imo2223 & Unknown protein & 5.2 & gi/16804262 & LM02223 & 11.3 & 13.5 & 4.3 & 3.99 & 5 & 47 \\
\hline (c3)111 & Imo2113 & Unknown protein & 5.2 & gi/16804152 & LM02113 & 28.9 & 28.8 & 5.0 & 4.80 & 8 & 23 \\
\hline (d3)112 & Imo0794 & $\begin{array}{l}\text { Similar to } B \text {. subtilis YwnB } \\
\text { protein }\end{array}$ & 5.2 & gi/16802836 & LM00794 & 29.0 & 23.3 & 5.3 & 5.11 & 6 & 28 \\
\hline (b4)113 & Imo0796 & Conserved hypothetical protein & 5.2 & gi/16802838 & LM00796 & 22.3 & 19.3 & 4.7 & 4.45 & 11 & 72 \\
\hline (b4)115 & Imo2748 & $\begin{array}{l}\text { Similar to } B \text {. subtilis stress } \\
\text { protein YdaG }\end{array}$ & 5.2 & gi/16804785 & LM02748 & 15.7 & 15.7 & 4.5 & 4.31 & 8 & 30 \\
\hline (b3)116 & Imo0437 & Conserved hypothetical protein & 5.2 & gi/16802481 & LM00437 & 31.6 & 30.4 & 4.7 & 4.85 & 11 & 37 \\
\hline (c5)120 & Imo0515 & Conserved hypothetical protein & 5.2 & gi/16802558 & LM00515 & 14.3 & 15.4 & 5.2 & 4.99 & 4 & 30 \\
\hline (d4)94 & Imo0592 & & 6 & gi/16802635 & LM00592 & 23.8 & 19.9 & 5.8 & 5.71 & 7 & 31 \\
\hline (f5)44 & Imo0775 & & 6 & gi/16802817 & LM00775 & 14.2 & 12.5 & 7.8 & 8.86 & 3 & 20 \\
\hline (b3)105 & Imo1059 & & 6 & gi/16803099 & LM01059 & 27.2 & 19.9 & 4.7 & 4.54 & 8 & 34 \\
\hline
\end{tabular}

Table 2. Identified proteins whose level of expression is modified during the stationary phase of growth in rich medium $(\mathrm{BHI})$ at $37^{\circ} \mathrm{C}$

\begin{tabular}{|c|c|c|c|c|c|c|}
\hline \multirow{2}{*}{$\begin{array}{l}\text { Protein spot } \\
\text { name }\end{array}$} & \multirow[t]{2}{*}{ Functional classes } & \multirow[t]{2}{*}{ Gene name } & \multirow[t]{2}{*}{ Description } & \multicolumn{2}{|c|}{$\%$ Vol. } & \multirow{2}{*}{$\begin{array}{l}\text { Ratio } \\
\text { (SP/EP) }\end{array}$} \\
\hline & & & & $\begin{array}{l}\text { Stationary } \\
\text { phase (SP) }\end{array}$ & $\begin{array}{l}\text { Exponential } \\
\text { phase (EP) }\end{array}$ & \\
\hline \multicolumn{7}{|c|}{ Overexpressed protein spots in stationary phase } \\
\hline Lmo0399 & $\begin{array}{l}\text { Transport/binding proteins and } \\
\text { lipoproteins }\end{array}$ & Imo0399 & $\begin{array}{l}\text { Similar to fructose-specific } \\
\text { phosphotransferase enzyme IIB }\end{array}$ & 1.248 & 0.210 & +5.95 \\
\hline Lmo26966 & $\begin{array}{l}\text { Metabolism of carbohydrates and } \\
\text { related molecules (specific } \\
\text { pathways) }\end{array}$ & Imo2696 & $\begin{array}{l}\text { Similar to hypothetical } \\
\text { dihydroxyacetone kinase }\end{array}$ & 0.293 & 0.145 & +2.03 \\
\hline $\mathrm{GlpD}(\mathrm{a})$ & $\begin{array}{l}\text { Metabolism of carbohydrates and } \\
\text { related molecules (specific } \\
\text { pathways) }\end{array}$ & $g / p D$ & $\begin{array}{l}\text { Similar to glycerol-3-phosphate } \\
\text { dehydrogenase }\end{array}$ & 1.163 & 0.574 & +2.03 \\
\hline $\mathrm{GlpD}(\mathrm{b})$ & & & & 2.411 & 0.564 & +4.27 \\
\hline $\mathrm{GlpD}(\mathrm{c})$ & & & & 0.453 & 0.000 & $\mathrm{~N}$ \\
\hline Lmo2743(a) & $\begin{array}{l}\text { Metabolism of carbohydrates and } \\
\text { related molecules (specific } \\
\text { pathways) }\end{array}$ & Imo2743 & Similar to transaldolase & 0.113 & 0.052 & +2.18 \\
\hline Lmo2743(b) & & & & 0.069 & 0.040 & +1.70 \\
\hline $\operatorname{PdhD}(\mathrm{a})$ & $\begin{array}{l}\text { Metabolism of carbohydrates and } \\
\text { related molecules (main } \\
\text { glycolytic pathways) }\end{array}$ & $\operatorname{pdh} D$ & $\begin{array}{l}\text { Highly similar to dihydrolipoamide } \\
\text { dehydrogenase, E3 subunit of } \\
\text { pyruvate dehydrogenase } \\
\text { complex }\end{array}$ & 0.276 & 0.135 & +2.04 \\
\hline $\operatorname{PdhD}(b)$ & & & & 0.413 & 0.202 & +2.04 \\
\hline $\operatorname{PdhD}(c)$ & & & & 0.203 & 0.137 & +1.48 \\
\hline Lmo1372 & Metabolism of lipids & Imo1372 & $\begin{array}{l}\text { Similar to branched-chain } \\
\text { alpha-keto acid dehydrog- } \\
\text { enase E1 subunit }\end{array}$ & 0.266 & 0.102 & +2.62 \\
\hline
\end{tabular}


Table 2. Continued

\begin{tabular}{|c|c|c|c|c|c|c|}
\hline \multirow{2}{*}{$\begin{array}{l}\text { Protein spot } \\
\text { name }\end{array}$} & \multirow[t]{2}{*}{ Functional classes } & \multirow[t]{2}{*}{ Gene name } & \multirow[t]{2}{*}{ Description } & \multicolumn{2}{|c|}{$\%$ Vol. } & \multirow{2}{*}{$\begin{array}{l}\text { Ratio } \\
\text { (SP/EP }\end{array}$} \\
\hline & & & & $\begin{array}{l}\text { Stationary } \\
\text { phase (SP) }\end{array}$ & $\begin{array}{l}\text { Exponential } \\
\text { phase (EP) }\end{array}$ & \\
\hline Lmo2101(a) & \multirow{4}{*}{$\begin{array}{l}\text { Metabolism of coenzymes } \\
\text { and prosthetic groups }\end{array}$} & \multirow[t]{4}{*}{ Imo2101 } & \multirow{4}{*}{$\begin{array}{l}\text { Similar to a protein required } \\
\text { for pyridoxine synthesis }\end{array}$} & 0.242 & 0.121 & +2.00 \\
\hline Lmo2101(b) & & & & 0.171 & 0.049 & +3.47 \\
\hline Lmo2101(c) & & & & 0.226 & 0.104 & +2.17 \\
\hline $\operatorname{Lmo2101(d)}$ & & & & 0.125 & 0.043 & +2.87 \\
\hline Lmo1367 & RNA synthesis (regulation) & Imo1367 & Similar to arginine repressor & 0.014 & 0.000 & N \\
\hline PyrR & RNA synthesis (regulation) & pyrR & $\begin{array}{l}\text { Highly similar to pyrimidine } \\
\text { operon regulatory protein }\end{array}$ & 1.919 & 0.425 & +4.51 \\
\hline RpmE & $\begin{array}{l}\text { Protein synthesis (ribosomal } \\
\text { proteins) }\end{array}$ & rpmE & $\begin{array}{l}50 \text { S ribosomal protein L31 } \\
\text { type B }\end{array}$ & 0.574 & 0.140 & +4.11 \\
\hline GroES & Protein folding & groES & $\begin{array}{l}\text { Class I heat-shock protein } \\
\text { (chaperonin) GroES }\end{array}$ & 0.206 & 0.081 & +2.55 \\
\hline Lmo1051 & Protein modification & Imo1051 & $\begin{array}{l}\text { Similar to formylmethionine } \\
\text { deformylase and to } B \text {. } \\
\text { subtilis YkrB protein }\end{array}$ & 0.240 & 0.120 & +2.00 \\
\hline LLO(a) & Miscellaneous & hly & Listeriolysin 0 precursor & 1.096 & 0.000 & $\mathrm{~N}$ \\
\hline $\mathrm{LLO}(\mathrm{b})$ & & & & 2.666 & 0.815 & +3.27 \\
\hline $\mathrm{LLO}(\mathrm{c})$ & & & & 2.145 & 0.479 & +4.48 \\
\hline $\mathrm{LLO}(\mathrm{d})$ & & & & 0.161 & 0.000 & $\mathrm{~N}$ \\
\hline $\begin{array}{l}\text { Fri(d) } \\
\text { Fri(b) }\end{array}$ & Adaptation to atypical conditions & fri & Non-heme iron-binding ferritin & $\begin{array}{l}0.169 \\
0.058\end{array}$ & $\begin{array}{l}0.041 \\
0.000\end{array}$ & $\begin{array}{l}+4.15 \\
\mathrm{~N}\end{array}$ \\
\hline Fri(c) & & & & 0.196 & 0.058 & +3.37 \\
\hline Lmo2256(b) & $\begin{array}{l}\text { Similar to unknown proteins (from } \\
\text { other organisms) }\end{array}$ & Imo2256 & Similar to unknown protein & 0.206 & 0.092 & +2.25 \\
\hline RpoZ & $\begin{array}{l}\text { Similar to unknown proteins (from } \\
\text { other organisms) }\end{array}$ & rpoZ & $\begin{array}{l}\text { Probable DNA-directed RNA } \\
\text { polymerase omega chain }\end{array}$ & 2.387 & 0.590 & +4.05 \\
\hline Lmo0775 & No similarity & Imo0775 & & 0.586 & 0.243 & +2.41 \\
\hline \multicolumn{7}{|c|}{ Underexpressed protein spots in stationary phase } \\
\hline Pgm & $\begin{array}{l}\text { Metabolism of carbohydrates and } \\
\text { related molecules (main } \\
\text { glycolytic pathways) }\end{array}$ & pgm & $\begin{array}{l}\text { Highly similar to phosphoglycerate } \\
\text { mutase }\end{array}$ & 0.077 & 0.163 & -2.11 \\
\hline Lmo1437 & $\begin{array}{l}\text { Metabolism of amino acids and } \\
\text { related molecules }\end{array}$ & Imo1437 & $\begin{array}{l}\text { Similar to aspartate-semialdehyde } \\
\text { dehydrogenase }\end{array}$ & 0.035 & 0.102 & -2.90 \\
\hline Lmo1496 & RNA synthesis (elongation) & Imo1496 & $\begin{array}{l}\text { Similar to transcription elongation } \\
\text { factor GreA }\end{array}$ & 0.292 & 0.595 & -2.04 \\
\hline RpsF & $\begin{array}{l}\text { Protein synthesis (ribosomal } \\
\text { proteins) }\end{array}$ & $r p s F$ & 30 S ribosomal protein S6 & 0.635 & 1.266 & -2.00 \\
\hline RplJ & $\begin{array}{l}\text { Protein synthesis (ribosomal } \\
\text { proteins) }\end{array}$ & rplJ & 50S ribosomal protein L10 & 0.398 & 0.812 & -2.04 \\
\hline Fri(a) & Adaptation to atypical conditions & fri & Non-heme iron-binding ferritin & 0.056 & 0.149 & -2.68 \\
\hline Lmo0127 & Phage-related functions & Imo0127 & $\begin{array}{l}\text { Weakly similar to protein gp20 } \\
\text { from bacteriophage A118 }\end{array}$ & 0.303 & 1.107 & -3.66 \\
\hline Lmo2256(a) & $\begin{array}{l}\text { Similar to unknown proteins } \\
\text { (from other organisms) }\end{array}$ & Imo2256 & Similar to unknown proteins & 0.128 & 0.264 & -2.10 \\
\hline
\end{tabular}

$\%$ Vol., volume of the spot divided by the total volume of all the spots in the 2-DE gels (Melanie III software) $\mathrm{N}$ : neosynthesized proteins in stationary phase of growth 